Balkan Araştırma Enstitüsü Dergisi / Journal of Balkan Research Institute Cilt/Volume 9, Sayı/Number 2, Aralık/December 2020, ss. 443-476.

Geliş - Received: 24.07.2019

Kabul - Accepted: 22.10.2020

DOI: 10.30903/Balkan.841154

ARASTTIRMA MAKALESI - RESEARCH ARTICLE

\title{
TRİADİK BAĞ TEORİSİ BAĞLAMINDA BATI TRAKYA MÜSLÜMAN-TÜRK AZINLIĞININ TÜRKIYYE İLE BAĞLAYICI İLIŞSKISİ
}

\section{Burcu TAŞKIN*}

\begin{abstract}
ÖZ
Bu çalışmada Batı Trakya Müslüman-Türk azınlığın ileri gelenleri, siyasi temsilcileri ile yapılan mülakatlarda ve yerel yayın organlarında sıkça dile getirilen ve nesilden nesile aktarıldığı göze çarpan "biz burada bırakıldık” söylemi güven teorileri ve azınlıkların soydaş ülke-vatan ülke arasındaki ilişkileri üzerine Brubaker'in öne sürdüğü triadik bağ teorisi kullanılarak incelenmiştir. 1920'den beri yerel ve ulusal düzeyde Yunan siyasetinde temsil edilen, 1981'den beri AB üyesi olan Yunanistan vatandaşı olan bu topluluk neden bu söylemi sürdürmektedir? Bu çalışma göstermiştir ki Yunanistan tarafından Lozan Anlaşması'na dayanarak etnik kimlikleri inkâr edilen, mütekabiliyet ilkesi altında sürekli azınlık haklarının ihlaline maruz kalan ve vatan ülke ile güven ilişkisi kuramayan bu topluluk, azınlık haklarının korunmasında Lozan Antlaşması'nı ve Türkiye'yi garantör unsur olarak görmektedir. Siyasi davranışlarında hem Yunan hem de Türk hükümetleri ile temas içinde olan azınlığın Türkiye ile olan güçlü bağının sürmesinde geç dernekleşme, siyasi-ruhani lider eksikliği, dil ve eğitim konusundaki yetersizlikler etkilidir.
\end{abstract}

Anahtar Kelimeler: Batı Trakya, Müslüman-Türk Azınlık, Türkiye, Yunanistan, Triadik Bă̆ Teorisi

* Dr. Öğr. Üyesi, İstanbul Medeniyet Üniversitesi, Siyaset Bilimi ve Kamu Yönetimi, İstanbul, ORCID: orcid.org/ 0000-0003-4504-2098, E-posta: burcu.taskin@medeniyet.edu.tr 
BURCU TAŞKIN

\title{
WESTERN THRACE MUSLIM-TURKISH MINORITY'S BINDING RELATIONS WITH TURKEY BASED ON TRIADIC NEXUS PERSPECTIVE
}

\begin{abstract}
This study analyzes the common discourse "we were left here" which is frequently expressed in the interviews made with Muslim-Turkish minority's prominents, political representatives, and in local broadcast organs, through utilizing trust teories and Brubaker's triadic nexus between the minorities- home states and kin states, showing the expression has been multiplied by generations. Why does this community which has been represented in Greek politics at local and national level since 1920 and citizens of an EU member state since 1981, maintain this discourse? This community, whose ethnic identity has been denied, its minority rights have been violated by Greece under the reciprocity rule, and fails to construct a trust relationship with the home state, perceives the Treaty of Lausanne and the kin-state Turkey as guarantor elements for the protection of their rights. This study claims that in terms of politial behavior, minority groups are in contact with both the Greek and Turkish governments. However, the continuation of strong bonds with Turkey originates due to their late organizational skills; the lack of a political and spiritual leader uniting them; weak abilities in their commands of language and several problems in education.
\end{abstract}

Keywords: Western Thrace, Muslim-Turkish Minority, Turkey, Greece, Triadic Nexus Theory

\section{Giriş}

6 Şubat 2019 tarihinde ilk kez bir Yunan Başbakanı, Alexis Çipras, Rum Ortodoks cemaati için önemli olan ve 1971 senesinde kapatılan Heybeliada'daki Ruhban Okulu'nu ziyaret etti. ${ }^{1}$ Hemen akabinde Türkiye Cumhurbaşkanı Recep Tayyip Erdoğan, Çiprasla birlikte düzenledikleri konferans sonrasında Ruhban Okulu'nun tekrar açılabileceğini ancak Yunanistan'ın Batı Trakya bölgesinde yaşayan çoğunluğu Müslüman-Türk nüfustan oluşan Müslüman cemaatin yaşam koşullarının iyileştirilmesini ve

\footnotetext{
$1 \quad$ https://www.ntv.com.tr/galeri/dunya/yunanistan-basbakani-ciprastan-ayasofyaya-veheybeliada-ruhban-okuluna-ziyaret,G344wH8WWkul_K68uXUx_A/gIkteVWipU64Zp9xDX VHaw, (22.02.2019).

Çipras: "dinler ve azınlıklarımızın hakları ve talepleri, yani Türkiye'deki Rum azınlığı ve Yunanistan'daki Müslüman azınlığı, müzakere ve pazarlık konusu olamaz. Onların haklarının korunması hükümetlerimizin asli sorumluluğudur.”
} 


\section{TRİADİK BAĞ TEORİSİ BAĞLAMINDA BATI TRAKYA MÜSLÜMAN-TÜRK AZINLIĞININ TÜRKIYYE İLE BAĞLAYICI İLIŞKİSI}

özellikle -1991 yılından itibaren Yunan devletinin Lozan Antlaşması'na uymayarak kendi ataması ile başlayan- müftülük sorunun çözümünü istediğini vurguladı. ${ }^{2} \mathrm{Bu}$ yüzden her ne kadar Çipras "azınlıklar" kelimesini ağzına almamayı tercih edip, azınlık meselesini ikili ilişkilerin dışında ve ülkelerin iç-meselesi olarak gördügünü ifade etse de, Türkiye'ye olan dördüncü resmi gelişinde Ruhban Okulu'nu ziyaret etmesi ve Erdoğan'ın söylemi Türkiye ve Yunanistan arasındaki ilişkilerde azınlık sorunun önemini ve karşılıklı adımlarla problemlerin çözümüne ulaşabileceğini de göstermesi açısından anlam kazandı.

Aynı hafta Batı Trakya'daki azınlık gazetelerinde iki politikacının ifadeleri "Ruhban Okulu'na Karşılık Müftülük"’3 ve "Çipras'ın Türkiye ziyaretinden azınlık ne bekliyor"4 başl1kları ile verildi (Gündem, 8 Şubat 2019; 15 Şubat 2019). Bu yayınlarda her ne kadar azınlık haklarının korunmasının hükümetlerin asli sorumluluğu olduğu görüşüne katıldıkları ancak azınlıklar konusunda atılacak adımlarda ilgili azınlıkların isteklerinin ve sorunlarının dinlenilerek karar alınması gerektiği vurgulansa da, azınlık meselesinin sadece iç-mesele olarak düşünülmemesi gerektiği ve 'mütakabiliyet ilkesinin's uygulanmasına olumlu yaklaşıldığı dikkat çeken bir unsurdu. Bu ziyaretten iki ay sonraki May1s 2019 Yunanistan yerel seçimlerinde ve Avrupa Parlamentosu (AP) seçimlerinde Çipras yönetimi önceki aşırı sağ partilerinden farklı politika geliştirememesinin, azınlığın etnik kimliğini tanımamasının ve azınlıkla ilgili konularda azınlık kurumlarını muhattap almamasının bedelini bu seçimde Müslüman-Türk nüfusun yoğunluklu yaşadığı Gümülcine (Rodop) ve İskeçe (Ksanthi) seçim bölgesinde oy kayb1 ile ödedi. Radikal-sol parti SIRIZA (Synaspismós Rizospastikis Aristerás) \%23.7 oy alırken merkez-sağ partisi Yeni Demokrasi

2 https://www.dailysabah.com/politics/2019/02/07/tsipras-first-greek-leader-in-decades-tovisit-historic-istanbul-seminary, (22.02.2019).

Erdoğan: "Yunanistan'da yaşayan soydaşlarımız ve Türkiye'deki Rum kökenli vatandaşlarımız bize göre birer ayrışma değil, aslında iş birliği vesilesidir. Azınlıklarımız bizler için sağlam birer köprüdür. $\mathrm{Bu}$ anlayışla görüşmelerimizde karşılıklı vatandaşlarımızın sorunlarını da değerlendirdik. Rum kökenli vatandaşlarımızın durumlarını daha da iyileştirmek için her türlü gayreti gösteriyoruz".

${ }^{3} \mathrm{http}: / /$ www.gundemgazetesi.com/PDF/gundem_1051.pdf, (11.04.2019).

${ }^{4} \mathrm{http}: / /$ www.gundemgazetesi.com/PDF/gundem_1050.pdf, (11.04.2019).

524 Temmuz 1923 tarihli Lozan Antlaşması'nın 37-45. maddeleri Türkiye ve Yunanistan'daki azınlıklara ekonomik, kültürel, inanç özgürlügüu, eğitim, dernekleşme alanlarında kısaca kollektif haklar tanır ve bu hakların korunması bakımından ülkeleri karşılıklı sorumlu kılar, azınlıklarının sorunlarının da nitelik ve nicelik yönünden karşılıklı olduğu belirtir. Aslında ülkelere karşılıklı sorumluluk veren bu maddeler zaman içinde "karşılık/mütakabiliyet ilkesi" olarak uygulanmaya başlamıştır. 


\section{BURCU TAŞKIN}

(Nea Demokratia/ND) \%33,1 oy ile seçimlerin galibi oldu. ${ }^{6}$ Daha da önemlisi güvenoyu anlamı taşıyan bu seçimi kaybederken, kendisine önceki genel ve yerel seçimlerde destek vermiş azınlığın oylarını ve güvenini de kaybetti. ${ }^{7}$ Temmuz ayında erken seçime gidilmesi kararlaştırıldı. Azınlık \%3 seçim barajına ve oy potansiyeli düşünüldüğünde (max. \%1) temsilci gönderemeyecek olmasını bilmesine rağmen AP seçimlerinde kendi etnik partisi Dostluk Eşitlik ve Barış Partisi'ne (DEB) oy verdi. DEB 40.000 oy ile 2014 AP seçimlerinde olduğu gibi Rodop ve İskeçe seçim bölgelerinde birinci parti olurken, azınlık bölgedeki siyasal etki gücünü AP'na ve Yunan partilerine göstermiş oldu. ${ }^{8}$

Azınlık grubunun "mütakabiliyet" ilkesine yaklaşımı ve siyasal davranışı Batı Trakya Müslüman-Türk cemaatine mensup araştırmacıların eserlerinde, gazetelerinde ve politikacılarla yapılan mülakatlarda öne çıkan ve Türkiye devletini azınlıktan sorumlu aktör olarak konumlandıran "Biz burada bırakıldık" söylemleri ile örtüşmektedir. ${ }^{9}$ Ancak mütakabiliyetin diğer tarafı olan İstanbullu Rumların sayısının 2000 kişiye düştüğü ve TürkiyeYunanistan ilişkilerindeki çözümlenmeyen sorunlar ve gerilim düşünüldüğünde bu söylem ne kadar rasyoneldir? Bu makale Batı Trakya Müslüman-Türk azınlığın nesilden nesile aktardığ 1 "biz burada bırakıldık"

62019 European Elections Results; https://election-results.eu/national-results/greece/20192024/, (25.03.2019).

${ }^{7}$ Burcu Taşkın, "SYRIZA's Electoral Victory in Greek Thrace: Impact of Muslim Minority Vote in the Changing Political System", Nationalism and Ethnic Politics, Cilt 23, Say1 2, 2017, ss.155-181.

${ }^{8}$ DEB, Türklerin yoğun olarak yaşadığ $\breve{g}_{1}$ Rodop ilinde, 23 bin 63 oy ve yüzde 38,00, İskeçe ilinde 15 bin 95 oy ve yüzde 25,24 oranıyla birinci olurken, Batı Trakya bölgesinin de içerisinde yer aldığı Doğu Makedonya eyaletinde ise Yeni Demokrasi Partisi (ND) ve Radikal Sol İttifak'tan (SİRIZA) sonra üçüncü sırada yer aldı. DEB'e, Oniki Adalar, Atina ve Selanik bölgelerindeki sandıklardan da yaklaşık bin oy çıtı.

${ }^{9}$ Abdürrahim Dede; Rumeli'nde Bırakılanlar (Batı Trakya Türkleri), Otağ Matbaası, İstanbul 1975; Ali Hüseyinoğlu, "Türk-Yunan Nüfus Mübadelesinin "Kalanlar"/“Bırakılanlar” Boyutu: Yunanistan'daki Batı Trakya Türkleri ve Geçmişten Günümüze Azınlık Eğitimi”. 6. Uluslararası Mübadele ve Balkan Türk Kültürü Araştırmaları Kongresi Bildirileri, Cilt 9, 2014, ss.239-256; Mülakatlar için bkz Burcu Taşkın, Political Representation of Minorities in Greece and Turkey: Nationalism, Reciprocity and Europeanization, Libra Yayınc1lı, İstanbul 2019. Bu söylem "Biz hep buradaydık ve burada olacağız" diyen İstanbul Rum Ortodoks cemaatinde görülmemektedir. Taşkın'a göre iki azınlık grubu arasındaki demografik özellikler; dernekleşme-örgütlenme becerisi; engeller ve olanaklar ve yaşadıkları ülkenin bu gruplara yaklaşımı siyasal davranış farkını doğurmaktadır. Osmanlı egemenliği döneminde hâkim elit yönetici grubunu oluşturan Balkanlardaki Müslümanlar, diğer gruplar gibi yerel dili öğrenme ve dernekleşme ihtiyacı duymamış, yeni ulus-devletlerin ortaya çıkması ile birlikte birden bire kendini Osmanlı mirasının devamı olarak algılanan Müslüman azınlık statüsünde bulmuşlardır. 


\section{TRİADİK BAĞ TEORİSİ BAĞLAMINDA BATI TRAKYA MÜSLÜMAN-TÜRK AZINLIĞININ TÜRKIYYE İLE BAĞLAYICI İLIŞKİSI}

söyleminin ve Türkiye ile olan bağlarının/ bağımlılıklarının nedenlerini araştırırken, azınlıkların haklarını ve kültürlerini korumada soydaş ülke (kinstate) ve yaşadıkları ülke (home-state) arasında nasıl bir stratejik denge kurduklarını incelemeyi amaçlamaktadır. Azınlıklar kolektif, birlik ve dayanışma içinde mi hareket etmektedirler? Azınlıklar sadece soydaş ülkenin (tarihsel, kültürel, linguistik veya etnik kimlik yakınlığı olan devlet) siyaseti ile uyumlu davranışlar mı göstermektedir, yoksa olanakları ve engelleri göz önünde bulundurarak farklı stratejiler belirleyebilirler mi? Bu bağlamda soydaş ülke ve yaşadıkları ülke arasındaki ilişki, güven meselesi ve azınlıkların bu ülkelere karşı geliştirdiği güven, cemaatlerin davranışlarını nasil etkilemektedir?

Bu soruları cevaplamak amacıyla araştırmanın ilk bölümü azınlıklar ile soydaş ülke (anavatan) ve yaşanılan ülke (vatan) arasındaki ilişki teorilerine ve özellikle 'güven' yaklaşımına odaklanacaktır. İkinci bölüm Batı Trakya'daki Müslüman-Türk azınlığın genel demografik özellikleri ve yaşadıkları problemler hakkında bilgi verecektir. Makalenin üçüncü ve asıl bölümü ‘Biz burada bırakıldık' söylemini ve azınlıkların soydaş ülke Türkiye ile olan ilişkisini teorilere dayanarak inceleyecek, son bölümde ise Müslüman-Türk azınlığın coğrafi yoğunluğu ve siyasal gücü elinde bulunduran bir grup olarak 'mütakabiliyet ilkesi' bağlamında Türkiye ve Yunanistan siyasetini nasıl etkileyebileceği ve bu ülkelerin geliştirmesi gereken azınlık politikalarını tartışacaktır.

\section{Azınlıklar ve Soydaş Devlet (Anavatan) - Yaşanılan Devlet (Vatan) İlişsisi}

Uluslararası ilişkilerde ve anlaşmalarda azınlıklar meselesi, azınlık haklarının tanımlanması ve korunması Birinci Dünya Savaşı'ndan itibaren öne çıkan önemli bir konudur. ${ }^{10}$ Azınlık kavramı ilk olarak 1919 Versailles Barış Konferansı'nda, Avusturya-Macaristan İmparatorluğu, Osmanlı İmparatorluğu ve Prusya Krallığı'nın dağılmasından doğan devletlerle

\footnotetext{
10 Örneğin 1648'de Protestan Alman nüfusuna dini hak tanıyan Vestfalya Antlaşması ya da İsveç ve Polonya tarafindan onaylanan Livonia'daki Roma Katolikleri lehine olan 1660'da Oliva ya da 1763 'te Fransa, İspanya ve Büyük Britanya arasındaki Kanada topraklarındaki Roma Katolikleri lehine olan Paris Antlaşması ile karşılaştırabiliriz. Daha ayrıntılı analiz için bkz: Natan Lerner, Group Rights and Discrimination in International Law, Martinus Nijhoff Publishers, Dordrecht/Boston/London 1991, ss. 7-22.
} 
yapılan barış antlaşmaları ile uluslararası anlaşmalara dâhil edildi. ${ }^{11}$ Anlaşmalar, Doğu ve Orta Avrupa'nın (Polonya, Yugoslavya, Çekoslovakya) yeni eyaletlerine, topraklarını arttıran devletlere (Romanya ve Yunanistan) ve yenilgiye uğrayan devletlere (Avusturya, Macaristan, Bulgaristan, Türkiye) azınlık halklarına karşı dini haklar ve siyasal eşitlik gibi bazı özel hakların tanınmasını zorunlu kılıyordu. Savaş sonrası kurulan Milletler Cemiyeti ve İkinci Dünya Savaşı'nı takiben yerini alan Birleşmiş Milletler gibi güçlü kurumların varlığına rağmen, 1990'lara kadar, azınlıklara hitap eden önemli uluslararası insan hakları kurumları yoktu. Soğuk Savaş'ın sona ermesi "azınlık meselesi" ve "kimlik politikaları" konularını siyaset bilimi gündemine tekrar taşırken, araştırmalar 1990'larda Balkanlar, Kafkaslar, Orta-Avrupa ve Afrika'da meydana gelen yıkıcı iç-savaşlar ve soykırıma varan etnik çatışmalara odaklandı. Soğuk Savaş sonrasındaki anlaşmalarda da önceki anlaşmalarda olduğu gibi azınlık hakları "kolektif haklar" olarak tanımlanmış ve bireysel vatandaşlık haklarının yanı sıra azınlıkların "fertlerin tek başına değil de ancak topluluk halinde kullanabileceği ve topluluk olmanın gereği yaşanabilecek hakları" garanti altına alınmıştır. Değişen coğrafyalarla beraber yeni ulus-devletler ortaya çıkarken, azınlık hakları ve bu hakların korunması ilkesini ülkelerin yönetim şekillerinden ve kültürlerden bağımsız evrensel prensiplere dayandırma çabasının arttığı görülmüştür.

Azınlık hükümlerini içeren ilk uluslararası anlaşmalarda, azınlık "ırksal, dini veya dilsel azınlıklara mensup kişiler" olarak tanımlanmıştır. Bu tanım farklı bir ırka, dine, dile ait olmak gibi nesnel ölçütlere dayanıyordu. Tanım da "irksal" kavramının dahil edilmesi, aynı zamanda, bu dönemde azınlıktan kastedilen şeyin şüphesiz "ulusal azınlık" olduğunu ortaya koymaktadır. Ulusal azınlık, bir akraba-devlete (kin-state) sahip olan kişidir; ahbap devlet adamlarının hâkim olduğu devlet. Azınlığın yaşadığı ve yurttaşlığa bağlı olduğu devlete ev sahibi devlet (home-state) denir. Kymlica, "ulusal azınlıklar" tanımı için bir devletteki varlığı sömürgeleştirme, fethetme veya zorunlu göç sonucu ortaya çıkan ve uzun süredir buradaki varlığı devam eden azınlık gruplarına atıfta bulunmaktadır. ${ }^{12}$ Ulusal azınlıklar, (en azından bazıları) ayrı kurumlar ve bazı siyasi özerklik düzeylerini talep etmeleri ile karakterize edilir.

11 19. yüzyıldaki yine üç önemli Kongre-Viyana (1814-15), Paris (1856), ve Berlin (1878)-, yabancı ülkelerin egemenliklerinde kalan nüfusların hakları ve güvenlikleri için "azınlıkları koruma" maddeleri içermektedir. Preece, Jennifer Jackson, National Minorities and the European Nation-States System, Oxford University Press, NY 1998, s. 15.

${ }^{12}$ Will Kymlica, Multicultural Citizenship, Oxford University Press, Oxford 1995, ss.10-33. 


\section{TRİADİK BAĞ TEORİSİ BAĞLAMINDA BATI TRAKYA MÜSLÜMAN-TÜRK AZINLIĞININ TÜRKIYYE İLE BAĞLAYICI İLIŞKİSI}

Azınlıkların tanınmasının yanısıra öncelikli problem 'azınlık tanımının' belirsizliğinde yatmaktadır. Juhn Raikka bu sorunu kısa ve öz olarak şu şekilde açıklar: "azınlıkların ne olduğu belli değildir". ${ }^{13}$ Raikka göçmen azınlıklar hakkındaki anlaşmazlıkları ve dilsel azınlıkların tanımlanmasındaki pratik sorunları vurgulamakta ve bu azınlıklara mensup kimseler ve azınlıkların korunmasıyla ne tür yükümlülükler öngördüğü ile ilgili birkaç soru ortaya atmaktadır. ${ }^{14}$ Bir azınlığın uluslararası hukuk amaçları için tanımlanması sorunu, uluslararası hukukçular ve akademisyenlerin, Milletler Cemiyeti'nin azınlıkların korunmasıyla ilgilendiğinden bu yana sıkıntı yaşamasına neden olmuştur. Neredeyse bir yüzyıl sonra ve hala uluslararası hukukta neyin azınlık oluşturduğuna dair kabul edilen bir tanım yoktur. ${ }^{15}$ Ayrıca, uluslararası belgeler tarafindan korunan azınlık türleri "etnik, dilsel ve din̂̂" azınlıklardan (ICCPR'da belirtilen) (CSCE ve Avrupa Konseyi belgelerinde) "ulusal" azınlıklara göre değişmektedir. ${ }^{16} \mathrm{Bu}$ tanım eksikliği genellikle konunun karmaşıklığına bağlanmaktadır. Bununla birlikte, azınlıklar konusuna dair geleneksel antipati ve "korku", ulusal hükümetleri uyarıya geçirmektedir.

Azınlıkların soydaş ülke ile bağımlılık ilişkisinin olması azınlık gruplarına ev sahipliği yapan ulus-devletleri endişelendirmektedir. 19. yy'da Çarlık Rusyası'nın Ortodoks milletinin koruyucusu olarak Osmanlı Devleti'nin içişlerine karışması, Yunanistan'ın Girit'in ve sonrasında Kıbrıs'ın bağımsızlığını ve Yunanistan ile birleşme politikasını (enosis) desteklemesi, Türkiye'nin Türk Kibrisliların koruyucusu olarak 1974'te adaya çıkartma yapması tarihte yaşanılan ve devletlerin azınlıklara karşı politikalarını oluşturan önemli örneklerdir. ${ }^{17}$ Yakın dönemde Akdeniz, Balkanlar ve Kafkaslar bölgelerine baktığımızda yeni ulus-devletlerin oluşumunda azınlıkların statüsündeki belirsizlikler göze çarpmaktadır. Bunun nedenleri arasında soydaş ülkelerin müdahalesi, eski elitlerin iktidarı paylaşmak istememesi veya yeni oluşan ulus devletlerde bu grupların azınlık konumunda olmamak için gösterdikleri şiddet politikasının getirdiği etnik

\footnotetext{
${ }^{13}$ Juhn Raikka, Do We Need Minority Rights? Conceptual Issues, Martinus Nijhoff Publishers 1996, s. 3.

${ }^{14}$ Raikka, a.g.e., s. 9.

${ }^{15}$ UN Declaration on the rights of Persons Belonging to National or Ethnic, Religious or Linguistic Minorities UN Res 47/135 of 18 Aralık1992.

${ }^{16}$ Uluslararası Medeni ve Siyasi Haklar Sözleşmesi (BM) International Conveniant on Civil and Political Rights (ICCPR); Avrupa Güvenlik ve İşbirliği Komisyonu, Commission on Security and Cooperation in Europe (CSCE).

${ }^{17}$ Richard Clogg, A Concise History of Greece, Cambridge Pub., Cambridge 1992, s. 29.
} 


\section{BURCU TAŞKIN}

çatışmalar sıralanabilir. 1990'larda Sırpların Bosna ve Kosova savaşlarındaki tutumu, Rusya'nın kendi azınlıklarını bahane ederek Çeçenya, Osetya ve en son Kırım'daki ilhak politikası "azınlıklar- soydaş ülke- yaşanılan ülke" denkleminin oluşturduğu sonuçlardır. ${ }^{18} \mathrm{Bu}$ sebeple azınlıklar meselesi literatürde genellikle "çatışma oluşma senaryoları" bağlamında ele alınmaktadır. ${ }^{19} \mathrm{Bu}$ çalışma ise Batı Trakya Müslüman Türk azınlığın söylemlerini ve Türkiye arasındaki ilişkiyi incelerken 'çatışma teorileri' bağlamında değil, "güven" ve "üçlü bağ ilişkisi" (triadic nexus) teorileri açısından ele alacak, azınlıkların varlığının ülkelerin demokratikleşmesine katkısı ve soydaş ülke (anavatan) ile yaşanılan ülke (vatan) arasındaki ikili ilişkileri güçlendirmesi olasılıkları üzerinden inceleyecektir.

Aslında insanlar arasındaki birçok çatışmanın arkasında güven eksikliği sorunu görülmektedir. Azınlık-çoğunluk arasındaki güven ilişkisi bu yüzden Brubaker ve Van Houten'ın öne sürdüğü ev sahibi hükümetler, ulusal azınlıklar ve soydaş devletlerinin arasındaki ilişkileri gerektiren triadik bağ ile ilişkilidir. ${ }^{20}$ Azınlık grubunun çoğunluk grup ve devletle ilişkisinde güven ne kadar az ise, grup soydaş ülkeye daha çok bağımlı hale gelmektedir. Toplumdaki azınlık ve çoğunluk ilişkisine ve etkileşimlerine bakıldığında psikolojik asimetri göze çarpmaktadır. ${ }^{21}$ Etnik veya dini çoğunluk gruba mensup bireyler kendi avantajlı durumlarının çok farkında değilken, azınlıktaki bireyler daha az değerli pozisyonlarının, aşağı muameleye maruz kalmalarının farkındadırlar ve ayrımcılığın ve önyargının çoğu zaman hedefi olurlar. ${ }^{22}$ Etnik-1rksal sosyalleşme çalışmalarına göre azınlık grubu ebeveynleri çocuklarına, çoğunluk mensuplarına karşı güvensizlik ve ihtiyatlı

\footnotetext{
${ }^{18}$ Christoph Zürcher, The Post-Soviet Wars: Rebellion, Ethnic Conflict, and Nationhood in the Caucasus, NYU Press, New York 2009. Susan Woodward, Balkan Tragedy: Chaos and Dissolution After the Cold War, Brookings Inst Pr., Washington DC 1995.

19 Özellikle topluluklar arasında şiddet olaylarını içeren çatışma çıktığında, gruplar arasında ilişkileri olumsuz etkilemektedir. Bu gerilim ve şiddet de önyargıların oluşmasını doğurur (bkz. Walter G. Stephan ve C.W. Stephan, "Intergroup anxiety", Journal of Social Issues, Cilt 81, 1985, ss.157-175), bu da ayrımcı davranışı ve güvensizliği beraberinde getirir (bkz. Daniel Bar-Tal ve Yona Teichman, Stereotypes and Prejudice in Conflict: Representations of Arabs in Israeli Jewish Society, Cambridge University Press, Cambridge 2005).

${ }^{20}$ Pieter Van Houten, "The role of a minority's reference state in ethnic relations", European Journal of Sociology, Cilt 39, No 1, 1998, ss. 110-146.

${ }^{21}$ Stephan ve Stephan, a.g.m., s. 165; Rogers Brubaker, Nationalism Reframed: Nationhood and the National Question in the New Europe, Cambridge University Press, New York 1996.

${ }^{22}$ Rezarta Bilali ve Ayşe Betül Çelik ve Ekin Ok, "Psychological asymmetry in minoritymajority relations at different stages of ethnic conflict", International Journal of Intercultural Relations, Cilt 43, 2014, ss. 253-264.
} 


\section{TRIADİK BAĞ TEORİSİ BAĞLAMINDA BATI TRAKYA MÜSLÜMAN-TÜRK AZINLIĞININ TÜRKIYYE İLE BAĞLAYICI İLIŞKİSI}

olma davranışlarını teşvik etmektedir. ${ }^{23}$ Diğer yandan, çoğunluk grubu ile bağların kurulması olanaklara erişim ve toplumla bütünleşmenin artmasını getirdiği için azınlık grubuna mensup bireylerin gruplar arası etkileşimi destekledikleri de görülmektedir. ${ }^{24}$

Ayrımcılığın hedefi olmak etnik grupların kimliklerini ön planda tutmalarını da beraberinde getirir, çoğunluk grupları ile karşılaştırıldığında etnik ve dini azınlıklar kendilerini kimlikleri ile daha güçlü ama ulusal çoğunluk kimliği ile daha zayıf şekilde özdeşleştiriler. Azınlıkların veya göçmenlerin coğrafi nüfus yoğunluğunun bulunması onların etnik dillerini, dini ibadetlerini ve kimliklerini sürdürmelerini sağlarken, çoğu zaman günlük hayatta, eğitimde ve yayın takip etmede iki dilli (bilingual) olmanın tercih edildiği görülmüştür. ${ }^{25} \mathrm{Bu}$ yüzden her ne kadar azınlık grupları soydaş ülkede ayrımcılığın hedefi olmadıkları ve dini, etnik kimliklerini daha açık yaşayabildikleri için daha güvenli hissetseler de sosyal ve siyasal davranışları sadece soydaş ülkeye bağlı değildir, yaşadıkları yerdeki yerel yönetimin tutumuna göre siyasal strateji geliştirirler. Diğer bir deyişle triadik- üçlü etkileşim içinde olasılık ve engelleri göz önünde bulundurarak "hayatta kalma" ve "kimliklerini koruma" içgüdüleri ile hareket ederler. ${ }^{26}$ Uluslar ve devlet sınırları çok nadir olarak örtüşür. Birçok devlet çok-uluslu ve etnik yapılıdır, etnik-dini ve kabile toplulukları tarihsel olaylar, savaşlar ve sömürge süreci sonucu birden fazla devletin sınırları içinde bölünmüştür. Azınlık grupları ile etnik, kültürel, dilsel veya tarihsel bağları olan çoğunluğa sahip komşu ülke olması durumunda azınlık meselesinin iki ülke arasındaki ilişkileri etkilemesi kaçınılmaz olmasa da yüksek olasılıkla muhtemeldir. Bu ulus-devletler içindeki azınlık ve çoğunluk ilişkisini ve azınlığın soydaş ülke ile olan ilişkisini daha karmaşı hale getirir. Nationalism Reframed adlı eserinde Brubaker bu üçlü ilişkiyi üç aktör arasındaki "ulusal azınlıklar, yaşadıkları ve vatandaşları oldukları vatan ülke (Brubaker'e göre yeni millileşmeye çalışan devlet) ve soydaş ülke (Brubaker'e göre vatandaşı

\footnotetext{
${ }^{23}$ Diana Hughes ve Rodriguez, J. ve Smith, E. P., Johnson, D., Stevenson, H., \& Spicer, P., "Parents' ethnic-racial socialization practices: A review of research and directions for future study", Developmental Psychology, No 42, 2006, ss. 747-770.

${ }^{24}$ Brock Bastian ve Lusher, D., ve Ata, A., "Contact, evaluation and social distance: Differentiating majority and minority effects", International Journal of Intercultural Relations, Cilt 36, Say1 1, 2000, ss. 100-117.

${ }^{25}$ John Edwards, "Sociopolitical aspects of language maintenance and loss: towards a typology of minority language situations", Maintenance and Loss of Minority Languages, (ed.) W. Fase ve K. Jaspaert ve S. Kroon, John Benjamins Publishing Co., Amsterdam 1992, ss. 37-54.

${ }^{26}$ Egor Fedotov, "Host governments, national minorities, and minorities' kin states: assessing the triadic nexus", Palgrave Communications, Cilt 3, Say1 23, 2017, ss. 1-5.
} 
olmadıkları ama ait oldukları veya ait oldukları yorumlanan dışarıdaki anavatan ülke), ve bu iki ülke ilişkisi” üzerinden açıklar. ${ }^{27}$

Bu üçlü ilişki ağı her zaman sabit ve aynı değildir. Brubaker'in Triadik bağ teorisinin temeli ise Birinci Dünya Savaşı sonrasında Avrupa'da son bulan üç çok-uluslu imparatorluğun (Habsburg, Osmanlı ve Romanov Rus Çarlığı) yeni oluşan ulus-devletlerde miras bıraktığı etnik ve dini toplulukların yarattığı "azınlıkların statüsü ve hakları" sorununa dayanmaktadır. Her ne kadar Brubaker'in bu teoriyi kullandığı ilk çalışmalar Orta Avrupa'daki Macar azınlıklar ve bu toplulukların Macaristan ile olan ilişkileri üzerinde şekillense de, teori Soğuk Savaş'ın sona ermesi ile yıkılan çok-uluslu ülkelerin -Çekoslavakya, Yugoslavya ve Sovyetler Birliğidevamında görülen etnik ve dini çatışmaları anlamak için de yazar tarafindan genişletilmiştir. Brubaker'in teorisi İkinci Dünya Savaş1 sonrasında Doğu Avrupa topraklarında kalan Alman nüfusun (Macaristan ve Polonya'daki Almanlar) ve diğer ülkelerden Batı Almanya'ya göç eden Alman nüfusun (ör. Romanyalı Almanlar) anavatan ve vatan ile süregelen stratejik ilişkisini çözümlemek için de kullanılmışıtır. ${ }^{28}$ Güncel olaylar temelinde Brubaker'in üçlü bağ yaklaşımı Rusya'nın Kırım'daki etnik Rus nüfusu koruma bahanesi ile (ve 2009'daki bu topluluğun Ukrayna karşıtı gösterilerine dayanarak) 2014'te Kırım'1 ilhak etmesi sürecini analiz etmek için yararlanılabilir. Ancak, literatürde Osmanlı İmparatorluğu'nun Balkanlardaki mirası olan etnik ve dini azınlık grupları ile Türkiye arasındaki ilişkileri, üçlü bağ teorisi bağlamında analiz eden çalışmalar bulunmamaktadır.

Azınlıkların talepleri ve iddiaları her zaman çoğunlukla ve merkez yönetimle aynı olmayabilir. Merkezi yönetim dil ve eğitim haklarının sunulması ile problemleri çözebileceğini ve azınlığı onurlandırdığını düşünürken, azınlık grubu ülke içinde belli bir bölgede kendi kendine yönetim yeterliliklerinin veya düzenlemelerin verilmesini hedefleyebilir. Bu yüzden ulusal azınlıkların talepleri varoluşları açısından önemlidir. ${ }^{29} \mathrm{Bu}$ noktada triadik bağ özellikle çoğunluk etnik gruba sahip yeni ulus devletlerde önem kazanır. Yukarıda da tarihsel örneklerle değinildiği üzere yeni ulus devlet karakterini oluşturmaya çalışan topluluklarda devlet yapısı daha çok çoğunluğun imtiyazlarını gözetecek şekilde oluşturulur ve bu yüzden

${ }^{27}$ Brubaker, a.g.e., s. 4.

${ }^{28}$ Cristian Cercel, "Postwar (West) German-Romanian Relations: Expanding Brubaker's Analytic Triad", Nationalism and Ethnic Politics, Cilt 23, Sayı 3, 2017, ss. 297-317.

${ }^{29}$ Donald L. Horowitz, Ethnic Groups in Conflict, University of California Press, Berkeley 1985. 


\section{TRİADİK BAĞ TEORİSİ BAĞLAMINDA BATI TRAKYA MÜSLÜMAN-TÜRK AZINLIĞININ TÜRKIYYE İLE BAĞLAYICI İLIŞKİSI}

azınlıklar kendi kimliklerini tehdit altında hissederler. Bu onları merkezi yönetim ile çatışmaya, pazarlıklara, ayrılma siyasetine veya çoğu zaman soydaş ülkeden olmak üzere dış destek talebine götürebilir. Bu da yeni ulusdevletlerde kendi kimliğine hatta egemenliğine bir tehdit olarak algilanabilir ve 'yaşanılan ülke- komşu soydaş ülke' arasındaki ilişkide ve ülke içindeki etnik azınlık-çoğunluk ilişkisinde gerilimlere yol açar.

Azınlıkların taleplerinin yerine getirilmesinde ve varoluşlarının devamında soydaş ülke ile yaşanılan ülke (vatan) arasındaki ilişki kimi zaman dengeleyici, kimi zaman ise engelleyici bir unsur olarak ortaya çıkar. Eğer soydaş ülke desteklerse ve sinyalleri gönderirse azınlık gruplar taleplerini radikalleştirmek gibi uygun davranışlarla bu sinyallere cevap verebilirler. Yine yaşanılan ülkedeki milliyetçilik türü ulus-devletlerin azınlıklara karşı politikasını- asimilasyon, dışlama veya uzlaşma- belirler. Mylonas'ın belirttiği gibi azınlıklar özellikle belirsizlik dönemlerinde ulus-devletlerin politikalarını öngöremedikleri için süreç hayati önem kazanabilir. ${ }^{30}$ Dolayısıyla, azınlık seçkinlerinin davranışları, sadece ev sahibi hükümetlerin yanı sıra akraba devletlerinin dâhil ettiği şeylere indirgenemez. Uluslararası aktörler ve kamuoyu da davranışları etkileyebilir. ${ }^{31}$ Soydaş ülkeler yaşanılan ülke ile olan ilişkilerinde etnik azınlıklara taraf seçmeleri konusunda baskı yapabilirler; diğer yandan etnik soydaşlarının vatandaşı olunan ulus-devlet tarafından tamamen dışlanmasını, sürülmesini veya imha edilmesini engelleyebilirler de. Bu yüzden iki ülke arasındaki ilişki, birbirlerini müttefik mi yoksa düşman mı gördükleri soydaş ülke ile bağları olan kendi ulusal azınlıklarına nasıl davrandıklarını belirler. Batı Trakya Müslüman-Türk azınlığın siyasal davranışları incelendiğinde Van Houten, Brubaker ve Mylonas'ın üçlü bağ ilişkisine ek olarak 'mütakabiliyet ilkesi' gereği diğer azınlık grup (Rum Ortodoks cemaati) ile olan ilişkisi ve 1990'lardan sonra uluslararası aktörler, uluslararası kamuoyunun ve Batı Trakya Müslüman diasporasının sorunlara farkındalık yaratmadaki etkileri de göz önünde bulundurulmalıdir.

\section{Batı Trakya Müslüman-Türk Azınlığı ve Temel Problemleri}

Batı Trakya, Trakya bölgesinin Yunanistan egemenliğinde kalan bölümüdür ve üç ilden oluşur: doğudaki Dedeağaç, ortadaki Gümülcine ve

\footnotetext{
${ }^{30}$ Harris Mylonas, The Politics of Nation-Building Making Co-Nationals, Refugees, and Minorities, Cambridge University Press, NewYork 2012, s. 12.

31 Erin K. Jenne, Ethnic Bargaining: The Paradox of Minority Empowerment, Cornell University Press, Ithaca 2007.
} 


\section{BURCU TAŞKIN}

batıdaki İskeçe. Batı Trakya, 1364'teki fetihten 1913 Balkan Savaşlarına kadar Osmanlı egemenliği altında kalmıştır. Bölgedeki Müslüman-Türk varlığının ortaya çıkışı konusunda iki görüş vardır. Bunlardan birincisine göre bölgedeki Türk varlığı Balkanlara M.Ö. II. yüzyılda ulaşan İskit Türklerinin ve Orta Asya'dan batıya göç eden kavimlerin gelişiyle başlamaktadır. Hun Türkleri M.S. IV. yüzyılda, Avar Türkleri V. yüzyılda, Peçenekler IX. yüzyılda ve Kuman Türkleri XI. yüzyılda buraya yerleşmişlerdir. Bu kavimlerin proto-Bulgarları oluşturduğu düşünüldüğünde bölgede Türk varlı̆̆ Osmanlı devletinin fethinden önce mevcuttur, bölge Osmanlı egemenliğine geçince İslam dinini benimsemişlerdir. ${ }^{32}$ Íkinci görüşe göre fetihten sonra Balkanlar'a Türk akını başlamıştır. Anadolu'nun Konya, Aydın, Balıkesir illerinden binlerce Türk ailesi buralara yerleştirilmiş, Osmanlı politikası gereği, Balkanlar'ın Türkleşmesi sağlanmıştır. ${ }^{33}$ Balkanların güneydoğu ucunda Asya'dan Avrupa'ya geçiş noktasında yer alması Trakya'yı stratejik hale getirmiş, bölgesel devletlerin yanında Trakya uluslararası müdahale alanı olmuştur.

Batı Trakya bölgesi 1913-1919 yılları arasında Bulgaristan yönetimi, 1919-1920 döneminde de Fransız mandası altında İtilaf Devletleri idaresi ve 1920 yılından itibaren de Yunan kontrolü ve siyasal yönetimi altında kalmıştır. Kurtuluş Savaşı'nın ardından imzalanan 1923 tarihli Lozan Antlaşması'nda, Türkiye'deki Rum Ortodoks nüfusu zorunlu olarak Yunanistan'daki Müslümanlarla nüfus mübadelesi ile yer değiştirmiştir. Öte yandan, yapılan nüfus mübadelesinden Yunanistan'daki Müslümanlar ile İstanbul Rum Ortodoks halkı karşılıklı olarak muaf tutulmuşlardır. Diğer bir deyişle, uluslararası bağlayıcı anlaşmaların yanısıra 1923 Lozan Antlaşması'nda belirtildiği üzere Türkiye ve Yunanistan karşılıklı olarak sınırları içindeki ulusal azınlıklarının haklarını korumak ve uygulamakla yükümlüdür. Antlaşmadaki 37.-45. maddelere göre Yunan ve Türk hükümetleri azınlık gruplarına "kanun önünde eşitlik, yaşam ve özgürlüklerinin korunmasi; özgür dolaşım hakkı" gibi tüm çoğunluk tarafından kullanılan bireysel vatandaş haklarının yanısıra 'anadilin özgürce kullanılması; dini ibadetlerin özgürce yapılması; kendi kurumlarını ve okullarını kurma ve kontrol etme hakkı; kendi dilinde eğitim' gibi kolektif haklar da tanır. Lozan Antlaşması'nın 45. maddesinde, Türkiye'deki Müslüman olmayan azınlığa tanınan hakların, karşılıklılık esasına göre,

\footnotetext{
32 Richard J. Crampton, A Concise History of Bulgaria, Cambridge Concise Histories, Cambridge University Press; 2. Bask1, New York 2006, s. 8.

${ }^{33}$ Adil Özgüç, Batı Trakya Türkleri, Kutluğ Yayınları, İstanbul 1974, ss. 16-17.
} 


\section{TRİADİK BAĞ TEORİSİ BAĞLAMINDA BATI TRAKYA MÜSLÜMAN-TÜRK AZINLIĞININ TÜRKIYYE İLE BAĞLAYICI İLIŞKİSI}

Yunanistan'daki Müslüman azınlığına da tanınması gerekliliği ifade edilmiştir. Sözleşme, Türkiye'nin Rum Ortodoksları ile Yunanistan'ın Müslümanları arasındaki nüfus değişimini, geleneksel dini kritere bağlı kalarak yaptı; dolayısıyla azınlık resmi olarak Yunanistan'da 'ulusal azınlık' olarak tanınır ve üç farklı etnik gruptan oluşan Müslüman azınlık olarak kabul edilir: Türkler, Pomaklar ve Romanlar. ${ }^{34}$ Lozan'daki din kriterinin altını çizerek Yunanistan Müslüman azınlığın etnik kimliğini gözardı ve Türk azınlığın varlığını inkâr etmektedir. Buna karşılık Türkiye, Müslüman olmayan Rum Ortodoks, Ermeni ve Musevi cemaatlerini ulusal azınlık statüsünde tanır; ancak Lozan Antlaşması'nda yer almayan Laz, Kürt, Bulgar gibi etnik kimlikleri azınlık olarak tanımlamaz. Batı Trakya'daki azınlık ise Türk basınında "Türk azınlık” olarak yer alır.

Ne yazık ki antlaşmanın hemen sonrasında her iki devlet de Lozan Anlaşmasının ulusal azınlıklara verdiği hakları ihlal etmeye başlamıştır. Lozan Antlaşması'ndaki devletlere azınlıklarını korumada sorumluluk getiren "mütakabiliyet ilkesinin" olumsuz bir şekilde istismar edilmesinin yanı sıra, Komisyon'un öngöremediği faktörler de bu zulmü getirdi. Yunan devleti, Batı Trakya'daki Müslüman azınlığ 1 ve özellikle Türk etnik grubu Osmanlı İmparatorluğu'nun devamı/mirası ve Türkiye'nin irredentalist amacının aracı olan güvenilemez "diğer" olarak gördü. İkinci Dünya Savaşı sonrasına kadar Yunan devletinin stratejisi azınlığa sadık olmama potansiyeline göre davranmaktır. Diğer bir deyişle Yunan devleti azınlığı Müslüman olarak tanımlamakta, ancak Türk olarak davranmaktadır. ${ }^{35}$

Bugün Batı Trakya, Doğu Makedonya ve Trakya idari bölgesinin parçasıdır ve üç vilayetten (seçim bölgesi) oluşur: İskeçe (idari merkez İskeçe), Rodop (idari merkez Gümülcine) ve Evros (idari merkez Dedeağaç). Trakya bölgesinin tüm nüfusu 340.000 kadardır. Müslüman nüfusun tam sayısı büyük orandaki göçler ve 1950'lerden beri resmi nüfus sayımı yapılmadığ 1 için bilinmemekle birlikte 90.000 ile 135.000 arasında tahmin

\footnotetext{
34 Yunan devleti 1930ların başı ve 1950lerde Türkiye-Yunanistan ilişkilerinin iyi olduğu dönem hariç tüm azınlığı dini grup olarak tanıyor ve grup içindeki Pomak ve Roman nüfusu olduğundan daha fazla belirtirken, Türkiye tüm azınlığı tek ve sadece Türk olarak düşünmektedir. Elisabeth Kontogiorgi, Population Exchange in Greek Macedonia: The Forced Settlement of Refugees 1922-1930, Clerdon Press, Oxford 2006.

${ }^{35}$ Kevin Featherstone ve Georgios Niarchos, The Last Ottomans: The Muslim Minority of Greece, 1940-1949, Palgrave Macmillan, Newyork 2011, s. 327.
} 


\section{BURCU TAŞKIN}

edilmektedir. ${ }^{36}$ Genel itibariyle Rodop bölgesinin yarı nüfusunun ve İskeçe vilayetinin üçte bir nüfusunun Müslüman olduğunu, Evros bölgesi de dâhil edildiğinde Müslümanların tüm bölgenin yaklaşık üçte bir seçmenini oluşturduğunu söyleyebiliriz. Bu çalışma "triadik bağ" kuramını incelerken Müslüman-Türk azınlığın önemli bir nüfusunu oluşturduğu Rodop ve İskeçe bölgelerine odaklanmaktadır. Dini-etnik özellikleri ve demografik kompozisyonunun yanısıra bölgenin ekonomik statüsü de azınlıkların siyasal temsiliyetini ve triadik bağ ilişkisini etkilemektedir. ${ }^{37}$ Müslüman Türk nüfusun en yoğunluklu yaşadığı Rodop aynı zamanda bölgedeki ve Yunanistan'daki 52 idari birim arasındaki en fakir yerdir. ${ }^{38}$ Gümülcine KINAL Partisi (Değişim için Hareket [Kinima Allagis]) milletvekili İlhan Ahmet'e göre topluluğun fakirliği ve toprağa bağl1 olması topluluğun bölgede nüfusunu sürdürmesini sağlamıştır. ${ }^{39}$ İskeçe'nin asıl ekonomisi Gümülcine ile karşılaştırıldığında tarıma değil ticarete dayanmaktadır ve bu yüzden de azınlık grubu Yunan nüfusu ile ekonomi ve sosyal alanlarda daha çok bütünleşmiştir ve Yunanca konuşma oranı da daha yüksektir.

Yukarıda değinildiği üzere Batı Trakya Türkleri, hukuki varlıkları Türkiye ve Yunanistan arasında yapılan ikili antlaşmalar ve uluslararası antlaşmalarla garanti altına alınmasına rağmen, bugün haklarını kullanamamaktan doğan birçok sorun yaşamaktadır. Bu sorunların en başında azınlığın Türk kimliğinin Yunan devleti tarafından inkâr edilmesi ve sadece

\footnotetext{
${ }^{36}$ Gümülcine Türk Konsolosluğu verileri 150.000-170.000 arasında vermektedir ve bu verilere dayanarak Türk diplomasisi de nüfus sayısını yüksek gösterme eğilimindedir. www.mfa.gov.tr/bati-trakya-turk-azinligi.tr.mfa, (18.03.2014).

Aarbakke'nin Yunan nüfus sayımına dayanan 1991 hesaplamasına göre İskeçe'de 39,115; Rodopta 56,865 ve Evros'ta 7,900; toplamda 103,880 Müslüman nüfus bulunmaktadır. İskeçe'deki Müslüman nüfusun \%19'u Türk, \%63 Pomak ve \%18'i Roma'dan oluşurken, Rodop'ta Türkler Müslüman nüfusun \%71'i ile çoğunluğu oluşturur, \%17 Pomak ve \%12 Roma nüfusu bulunmaktadır. Vermund Aarbakke, The Muslim Minority of Greek Thrace, Doktora Tezi, University of Bergen, Bergen 2000, ss. 31-35.

37 Geoffrey Alderman ve John Leslie, Governments, Ethnic Groups and Political Representation: Comparative Studies on Governments and Non-dominant Ethnic Groups in Europe, 1850-1940, Dartmouth Publishing, New York 1993.

${ }^{38}$ Dia Anagnostou ve Anna Triandafyllidou, "Regions, minorities and European integration: A case study on Muslims in Western Thrace, Greece", ELIAMEP Reports, Athens 2006.

39 "İlhan Ahmet ile mülakat 21 Nisan 2013. 2019 seçimlerinde merkez-sol KINAL Partisi milletvekili olarak seçilen Ahmet, mülakat yapıldığg tarihte milletvekili değildir, ancak bir önceki dönem merkez-sağ Yeni Demokrasi partisinden milletvekili olarak seçilmiştir. Bu görüşmede Ahmet 'fakirliğimiz bizi kurtardı' ifadesini kullanmıştır. Diğer bir deyişle ekonomik imkânlarının kısıtlı olması ve geçim aracı olarak toprağa bağlı olmak Müslüman topluluğun başka bir yerde yeni bir hayat kurmasını engellemiştir.
} 


\section{TRİADİK BAĞ TEORİSİ BAĞLAMINDA BATI TRAKYA MÜSLÜMAN-TÜRK AZINLIĞININ TÜRKIYYE İLE BAĞLAYICI İLIŞKİSI}

Müslüman olarak tanımlanmasının tercih edilmesidir. ${ }^{40}$ Oysa anket çalışmaları göstermiştir ki azınlık nüfusu her ne kadar dini ibadetlerini, geleneklerini sürdürse de "kendinizi hangi kimliğe ait hissediyorsunuz" sorusuna katılımciların \%89'u Türk, \%4'ü Yunan ve \%7'si hem Türk hem Yunan yanıtını vermiștir. Batı Trakya Türkleri dini geleneklerine bağlı kalmakla birlikte, Yunan devlet politikasının "dinî cemaat" dayatmalarına rağmen Batı Trakya Türkleri dinin bireysel inanç boyutu ile "cemaat" genellemesi arasında keskin bir çizgi çizmektedir. ${ }^{41} \mathrm{Bu}$ yüzden en son 2018'de Siriza hümüketinin müftülerin yarg1 yetkisini azaltan (kadı statüsüne benzer) ve azınlık için yalnızca şeriat mahkemelerine değil, Yunanistan mahkemelerine de gidebilme tercih hakk1, toplumda karşılı̆g1 olan bir yasal düzenlemedir ve Şeriat'ın muhafazası konusunda Yunan devletinin ısrarını kırmıştır. İkinci sorun çoğunlukla tarım ve hayvancılık ile geçinen Müslüman azınlığa ait olan toprakların kamulaştırılmasıdır. Azınlık aleyhine uygulanan iskân ve mülkiyet politikaları neticesinde süreç içerisinde bölgedeki Türk varlığının toplam nüfus içindeki payının $\% 67$ 'den $\% 33$ 'e, işlenebilir arazide Türk azınlığı payının \%84'ten \%18'e (yaklaşık olarak) gerilediği görülmektedir. Nüfusun yaklaşık \%80'inin tek geçim kaynağının toprak olduğu dikkate alındığında mülkiyet değişiminin çok ciddi ekonomik sonuçları olduğu açıktır. ${ }^{42}$ Üçüncü problem yaklaşık 50.000 azınlık üyesinin 1998 senesinde kaldırılana kadar 19. madde uygulaması ile ülke dışına çıktıkları anda yasadışı olarak Yunan vatandaşlığından çıkarılmaları ve haymatlos (vatansız) statüsünde kalmalarıdır. Dördüncü önemli sorun Lozan Antlaşması'ndan bahsedilmesine rağmen azınlığın kendi cemaat vakıflarına ait mal ve mülklerin yönetimini elinde bulundurmamasıdır. ${ }^{43}$ Beşinci ve gündemi en çok meşgul eden-Cumhurbaşkanı Erdoğan'ın da yazının başında dile getirdiği- sorun ise yine Lozan Antlaşması ile tanınan ancak 1967 askeri cuntası ile ihlal edilmeye başlanan müftülerin doğrudan seçilmesi

\footnotetext{
${ }^{40}$ Lois Whitman, Destroying Ethnic Identity - The Turks of Greece, Helsinki Watch Report, New York, 1990; Baskın Oran, Türk Yunan İlişkilerinde Batı Trakya Sorunu, Mülkiyeliler Birliği Yayınları, Ankara 1992.

${ }^{41}$ Kadir Yalınkılıç ve Kutlay Yağmur, "Batı Trakya Türklerinin Anadillerine ve Kültürlerine Karş1 Tutumları", Bilig, Say1 70, ss. 283-308.

${ }^{42}$ Ahmet Serdar, "Tarihsel Süreç İçerisinde Batı Trakya Türklerinin Ekonomik ve Demografik Gelişimi”, Balkan Araştırma Enstitüsü Dergisi, Cilt 3, Sayı 2, Aralık 2014, ss. 97-126.

${ }^{43}$ Yunan Vatandaşlık Yasasının 19. maddesine göre (No:3370/1955) "Yunan etnik kökenli olmayan bir kişi geri dönüş amacı olmadan Yunanistan'dan ayrılırsa Yunan vatandaşlığını kaybeder". 1959 senesinde uygulamaya konan madde Yunan Parlamentosu tarafindan Haziran 1998 senesinde kaldırılmıştır.
} 


\section{BURCU TAŞKIN}

meselesidir. ${ }^{44}$ Aslında 1980'lere kadar müftülerin seçimi konusunda Yunan devleti ile azınlık arasında bir çatışma bulunmamaktadır, ancak 1985'te Gümülcine ve İskeçe'de Yunanistan'in müftüleri valiler tarafından atamaya başlaması ile müftü sorunu ortaya çıkar. Sonrasında Yunan devleti müftüyü Ortodoks din adamları tarafindan oluşan bir heyet tarafından belirleyip devlet memuru statüsünde atamaktadır, aynı zamanda Müslüman azınlık da kendi müftüsünü seçimle belirlemektedir. 19 Ocak 1991 tarihinde cemaat sadece kendi seçtiği müftüyü tanıyacağını duyurmuştur ve bu yüzden 'atanmış ve seçilmiş' müftü iki başlılığ seçilmiş müftü Mehmet Emin Ağa müftü meselesinin ve mücadelesinin sembol ismi haline gelmiştir. Günümüzde dahi Çipras'ın İstanbul'daki Ruhban okulunun tekrar açılmasını istediği dönemde İskeçe ve Gümülcine'deki müftülük makamlarına hükümet tarafindan atama yapılmasını eleştirdikleri için Batı Trakyalı iki gazeteci Cengiz Ömer ve Feyzullah Hasankahya $15^{\prime}$ er ay hapis cezasına mahkûm edilmişlerdir. ${ }^{45}$

$\mathrm{Bu}$ siyasal sorunlara ek olarak azınlığın en temel kültürel talebini eğitim sisteminde reform ve iyileştirme oluşturmakta. Lozan Antlaşması'na göre Batı Trakya'daki Müslüman azınlığa kendi anadilinde eğitim hakkı tanınmıştır; ancak azınlığa mensup öğrenciler karışık eğitim sistemi, eski müfredat kitaplar, iyi eğitim almamış öğretmenler ve verimli bir okul müfredatı olmadığı için iyi Yunanca veya Türkçe dili öğrenememekte ve eğitim alamamaktadır. Azınlığın ileri gelenlerine göre ise anadilde eğitimin anaokullarında başlaması gerekiyor, ancak Yunan devleti anaokullarında Yunancayı zorunlu kılıyor. ${ }^{46}$ Kendilerini Türk veya Müslüman Türk olarak tanımladıkları için cemaat, çocuklarını eğitim kalitesi daha düşük olsa da azınlık okullarına göndermeyi tercih ediyor. Bu okullar sayesinde Türklük ve İslami değerler ile kültür daha genç nesillere aktarılabiliyor. Bu yüzden azınlık bu kurumların varlığını kendi varlığının bölgedeki devamının garantör unsuru olarak yorumluyor. Azınlığın eğitim seviyesinin artması aynı zamanda ayrımcılığa karşı farkındalık ve mücadele etme olanaklarını beraberinde getirir. Diğer bir deyişle eğitim olanakları etnik kimliğin sürekliliğini

\footnotetext{
${ }^{44}$ Stephanos Stavros, "The Legal Status of Minorities in Greece Today: The Adequacy of their Protection in the Light of Current Human Rights Perceptions", Journal of Modern Greek Studies, Cilt 13, Say1 1, 1995, ss. 1-32; Turgay Cin, Yunanistan'daki Müslüman Türk Azınlı̆̆ın Din ve Vicdan Özgürlüğü: Baş Müftü ve Müftülükler Sorunu, Seçkin Yayınları, Ankara 2003. 45 https://www.sabah.com.tr/dunya/2018/06/08/bati-trakyada-muftu-atamasini-elestirengazetecilere-hapis., (17.09.2018). Ömer ve Hasankahya'nın cezaları 3 yıl ertelenmiş ve serbest bırakılmışlardır.

46 İskeçe Türk Gençlik Derneği eski başkanı Ahmet Kara ile mülakat, 21 Nisan 2013.
} 


\section{TRİADİK BAĞ TEORİSİ BAĞLAMINDA BATI TRAKYA MÜSLÜMAN-TÜRK AZINLIĞININ TÜRKIYYE İLE BAĞLAYICI İLIŞKİSI}

getirmesi açısından önem kazanıyor. Azınlıktaki kız öğrencilerin eğitim ve okur-yazarlık oranı da düşüktür ve topluluk için kültür ve geleneklerin ve anadilin aktarımında bir engel oluşturmaktadır. Ancak 1990'lardan sonra kız öğrenciler yüksek öğretim okullarına girmeye başlamıştır. Yunan devletinin 1996 senesinde azınlık ögrenciler için üniversitelere \%0,05 kota getirmesi cemaat tarafindan olumlu karşılanmış ve Yunan okulları ilkokuldan üniversiteye daha çok tercih edilmeye başlanılmıştır. Yine de Yunan diline hâkimiyet konusunda sorun yaşayan ve ekonomik az gelişmişlik nedeniyle de kaliteli eğitime erişimi kısıtlı olan Müslüman azınlık öğrencileri daha iyi bir eğitim için Türkiye'deki üniversiteleri tercih etmektedir.

Bu doğrultuda Yunan hükümetlerinin eğitim politikası azınlıkla olan "güven ilişkisini" ve soydaş Türkiye devletini dâhil eden triadik bağ kuramını yorumlamak açısından önemlidir. 1950-1955 yılları arasında cemaat seçimlerinde özgürlük, Türk öğretmenler, Türk okulları gibi haklar tanınmışsa da Yunan Hükümeti'nin ekonomik baskıları ve bölge Türklerini Türk inkılâbından faydalandırmamaya varan tavırları Batı Trakya Türklerini rahatsız ediyordu ${ }^{47} 1955$ senesiyle birlikte ise Batı Trakya Türkleri için daha sorunlu bir dönem başladı. 1980'lerin sonunda Bulgar devletinin Türk azınlığa karşı uyguladığı asimilasyon politikalarının yarattı̆̆ geçmiş deneyimlerin Batı Trakya Müslüman liderleri tarafından da dikkate alındığı görülmüştür. Örneğin Akın gazetesinin sahibi ve eski bir milletvekili olan Hasan Hatipoğlu Yunan devletinin Müslüman azınlığa karş1 'Helenleştirme politikası' uyguladığını öne sürmüş, ${ }^{48}$ "bugünkü hükümet eğer Bulgarların yaptığı gibi bir asimilasyon uygulamak isterse, bu yanlış bir politika olacaktır" ifadesinde bulunmuştur. ${ }^{49}$ Kıbrıs sorunuyla birlikte, Türk-Yunan ilişkileri son derece gergin bir hal aldı. 1990'larda Batı Trakya Türklerinin yaşadığı sorunların uluslararasılaşması ve Yunanistan'ın demokratikleşmesi ile birlikte bireysel haklar alanında olumlu adımlar atılsa da özellikle Kuzey Kıbrıs Türk Cumhuriyeti'nin 1983 senesinde kurulması ve bağımsızlığını ilan etmesi ile birlikte 1990'lardan sonra bölgedeki Müslüman Türk azınlık üzerindeki baskı ve hak ihlalleri artmıştır. 1988 Davos zirvesinde dönemin Dışişleri bakanı Mesut Yılmaz Batı Trakya'daki Türk azınlık sorununu gündeme taşımış, Kıbrıs'taki iki topluluk bir çözüm üzerine anlaşmadan adadaki Türk askerinin çekilmeyeceğini belirtmiştir. ${ }^{50}$

\footnotetext{
47 Tsitselikis Konstantinos ve Mavrommatis, Giorgos, "The Turkish language in Education in Greece", Mercator-Education Report 2003.

${ }^{48}$ Akın Gazetesi Arşivi, 27 March 1987.

${ }^{49}$ Akın Gazetesi Arşivi, 3 April 1987.

${ }^{50} \mathrm{Clogg}$, A Concise History of Grece, s. 189.
} 


\section{BURCU TAŞKIN}

Türkiye'ye ve Avrupa ülkelerine daha iyi eğitim ve iș imkânları için göçen, burada eğitim alan ve Yunan vatandaşlı̆̆ını devam ettiren topluluğun hem etnik kimlik bilincinin geliştiği, hem Türkiye ile bağlarını kuvvetlendirdiği hem de Yunan devletinin gerçekleştirdiği hak ihlali meselesini uluslararasılaştırmayı başardığı görülmektedir. ${ }^{51}$ Ayrıca, Yunanistan'ın Batı Trakya'daki durumla ilgili azınlık politikasını ciddi şekilde eleştiren ilk uluslararası rapor 1990'da Human Rights Watch (HRW)'den geldi ve Batı Trakya'nın azınlık politikasını değiştirmek için Yunanistan'a daha fazla baskı yapıldı.

Bugün Batı Trakya'daki azınlık, kamu hizmetlerinin ve ekonomik koşulların dezavantajlarından muzdarip olmaya devam ediyor. YunanistanTürkiye-azınlık üçgeni içindeki güç ilişkilerine bakarsak, azınlık her zaman en zayıf parçayı oluşturuyor. Kendi başına etki yaratmak ve politikayı belirlemek için yeterli bir politik, kültürel ve ekonomik güce sahip değil. Kültürel alanda, güç ilişkileri, eğitimle ilgili sorularda kendilerini açıkça göstermektedir. $\mathrm{Bu}$ dezavantajlardan daha derin etki ise topluluğun günlük hayatta maruz kaldığı sosyal davranışlardır. Ancak bu durum, azınlık ile çoğunluk arasındaki gerilimin Yunanistan'daki tüm bölgelere yayıldığı anlamına gelmemelidir.

Bir azınlık mensubu, Batı Trakya kamu görevlilerinden bir ehliyet alamadığında, onu Yunanistan'ın diğer bölgelerinden alabileceği bilinmektedir. $\mathrm{Bu}$, bölge dışındaki azınlığa yönelik hiçbir ayrımcılık vakasının olmadığını veya çok az olduğunu göstermektedir. Ayrıca, Hüseyinoğlu'na göre, Batı Trakya dışında yaşayan nüfus azınlığın sorunlarından, devlet ayrımcilığından ve hak ihlallerinden haberdar değildir. ${ }^{52}$ Yine de kamuda çalışan Müslüman azınlık oranı, azınlığın genel nüfusa oranının çok altındadır. Bunun nedeninin resmi olmadan uygulanan (informal) ayrımcılığın yanısıra, yukarıda da bahsedildiği gibi azınlık nüfusun Yunanca dil bilgisindeki ve eğitim seviyesindeki yetersizlikten kaynaklandığ1 düşünülebilir. ${ }^{53}$

${ }^{51}$ Cafer Alioğlu, Batı Trakya Davası'nın Avrupa Cephesi, İnal Ofset, İstanbul 1998.

${ }^{52}$ Hüseyinoğlu, "Türk-Yunan Nüfus Mübadelesinin "Kalanlar"/ "Bırakılanlar" Boyutu”, s. 250.

53 Country Report on Human Rights Practices for 1999- Volume II, https://www.govinfo.gov/content/pkg/CPRT-106JPRT63935/html/CPRT-106JPRT63935VolumeII.htm; Study on employment and the prospects of job creation in Rhodope-Evros, Prefecture of Rhodope, Evros, Komotini, November 2004, ss. 14-15. 


\section{TRİADİK BAĞ TEORİSİ BAĞLAMINDA BATI TRAKYA MÜSLÜMAN-TÜRK AZINLIĞININ TÜRKIYYE İLE BAĞLAYICI İLIŞKISSI}

$\mathrm{Bu}$ noktada Yunan Parlamentosu'nda azınlı mensubu milletvekillerinin varlığı ve çalışmaları, cemaatin taleplerinin ve sorunlarının ülke çapında gündeme getirilmesi ve karşl1ıklı barışçıl diyalogla çözüm bulunması açısından önem kazanmaktadır. Gümülcine ve İskeçe'de ağırlıklı olarak Müslüman milletvekillerinin seçilmesi her ne kadar azınlık-çoğunluk gerilimini zaman zaman yaratsa da, milletvekilleri ulusal ve yerel seçimlerde Yunan partilerinden aday olmakta ve seçilmekte, ilişkileri yasal siyasal zeminde çözme eğilimlerini göstermektedirler. Farklı görüşlerden olsalar ve farklı partilerde bölge milletvekili olarak yer alsalar da, azınlık kökenli milletvekillerinin İlhan Ahmet'in ifade ettiği gibi 'azınlık içinde partizanlık değil, partiler içinde azınlık hakları taraftarı' politikaları benimsediği göze çarpar. ${ }^{54}$ Diğer yandan girişte de değinildiği üzere Avrupa Parlamentosu seçimlerinde kendi etnik partilerine oy vererek azınlık meselesini ve Yunan devletinin ihlallerini uluslararasılaştırma başarısını gösterebilecek oy gücüne de sahip bulunmaktadır. Bu yüzden 1920'den beri - 1993 hariç- Yunan meclisinde temsil edilen, 1981 senesinden beri $\mathrm{AB}$ üyesi Yunanistan vatandaşı olan Batı Trakya Müslüman Türk azınlığının 'biz burada bırakıldık' söylemini ve Türkiye ile olan bağını/bağımlılığını devam ettirmesi ilgi çeken ve incelenmesi gereken bir yaklaşım olarak aşağıdaki bölümde irdelenecektir.

\section{3. "Biz Burada Bırakıldık" Söylemi ve Triadik Bağ Kuramı}

Rogers Brubaker triadik (üçlü) bağı ulusal azınlıklar, uluslaşmakta olan devlet (yaşanılan/vatandaşı olunan ülke) ve dişardaki ulusal anavatan (soydaş ülke) arasında tanımlar. Anavatan soydaş ülke Türkiye ile olan bu bağ özellikle Osmanlı Devleti'nin dağılmasından sonra yerine kurulan uluslaşmakta olan yeni devletler ve bu sınırlar içinde kalan ve kendilerini birden azınlık statüsünde bulan Müslüman-Türk topluluklar arasında görülmektedir.

Yurtdışı Türk toplulukları olarak tanımlanan ${ }^{55}$ ve Türkiye devletinin sağladığı burslarla da Türkiye'de eğitim, barınma ve çalışma hakları sunulan bu topluluklar ağırlıklı olarak Balkan bölgesindeki Müslüman-Türk

\footnotetext{
54 İlhan Ahmet ile mülakat, 21 Nisan 2013.

55 Yurtdışı Türkler ve Akraba Topluluklar Başkanlığı (YTB) 2010 senesinde kurulmuştur. Sadece Balkanlardaki Türk etnik kökenli azınlıkları ve Batı Avrupa ülkeleri vatandaşı olan Türk diasporasını değil, 'kardeş' ve 'akraba' toplululuklar ismi altında daha geniş bölgedeki Türk kökenli olmayan ama tarihsel ve kültürel bağı bulunan Müslüman cemaatlere de hizmetler ve etkinlikler sunmaktadır. https://www.ytb.gov.tr/, (11.03.2019).
} 
azınlıkları kapsamaktadır. Türkiye sınırları dışındaki tarihsel ve kültürel bağları olduğu Türk ve Müslüman topluluklara yönelik politikasını şu şekilde tanımlamaktadır: "Dildaş, dindaş, soydaş ve gönüldaş topluluklara yönelik unutulmaya yüz tutmuş ortak değerlerin yeniden tesisine ilişkin çalışmalar yapmak ve [ilişkileri] ekonomik, sosyal ve kültürel bağlar geliştirmek amacı ile insan odaklı bir yaklaşımla sürdürmek".

Dolayısıyla Türkiye açısından tarihsel, kültürel, dilsel, dinsel ve hatta coğrafi bağı en kuvvetli olan topluluklar sınır komşuları Yunanistan ve Bulgaristan'da yaşayan Türk-Müslüman azınlıklardır. Türkiye'nin Yunanistan'da beş adet (Atina'da iki; Rodos, Gümülcine ve Selanik'te birer tane) Bulgaristan'da üç adet (Sofya; Burgaz ve Filibe) dış temsilciliklerinin bulunması bu ülkeler ve topluluklarla arasındaki ilişkinin Türkiye'nin dış politikası için ne kadar önemli olduğunu gösterir. Öte yandan bu bağ ve Türkiye'nin yurtdışı Türk topluluklara yönelik politikası, azınlıklarını Osmanlı mirası ve güvenilmez bir unsur olarak gören bu ulus devletlerde (vatandaşı olunan ülke) çoğu zaman tehdit olarak algılanmaktadır. Özellikle nüfus olarak siyasal gücü elinde bulunduran, kendi etnik partileri olan ve ulusal seviyede siyasal temsiliyet olanaklarına sahip bu toplulukların siyasal davranışlarında Türkiye'nin Konsoloslukları aracılığı ile etkisi olduğu tartışması sık sık gündeme gelmektedir. ${ }^{56}$

Yine de Yunanistan ve Bulgaristan azınlıkların Türk kimliğini bastırmada ve asimile etmede farklı siyasetler geliştirmiştir. Bulgaristan sosyalist rejim sırasında İslam dini kimliğini ortak yurttaşlık ve yoldaşlık politikası ile azaltmış, Soğuk Savaş sonrasında ise Bulgarlaştırma politikası ile tam bir asimilasyon uygulamasına yönelmiştir. Yunanistan ise Lozan Antlaşması'na dayanarak azınlığı sadece Müslüman olarak kabul etmiş ve Türk kimliği bilincini azaltmak için İslamlaştırma politikasını yürütmüş ve İslami yaşayış biçiminin sürdürülmesini desteklemiştir. Bu politikalar ise beklenenin tersine anavatan Türkiye'nin güvenli bir liman olarak görülmesine ve bağların daha çok güçlenmesine yol açmıştır. Diğer bir deyişle ulusdevletin tarihsel düşmanı olarak konumlanan soydaş ülke olarak Türkiye'nin varlığı azınlıkların günlük yaşamlarında baskı ve ayrımcılığa maruz kalmalarına yol açarken, tamamen asimile olmalarını ve etnik şiddet politikasına uğramalarını engellemiştir. Bu yüzden "biz burada bırakıldık"

56 “Türkiye'nin Yunanistan'daki Müslüman Azınlığı Etkilemesinden Kim Sorumlu?" (Türkçe)https://greece.greekreporter.com/2019/05/28/whos-responsible-for-letting-turkeyinfluence-greek-muslim-minority-in-thrace/, (09.06.2019). 


\section{TRİADİK BAĞ TEORİSİ BAĞLAMINDA BATI TRAKYA MÜSLÜMAN-TÜRK AZINLIĞININ TÜRKIYYE İLE BAĞLAYICI İLIŞKİSI}

söylemi öncelikle yaşanılan baskıları, bu baskılara karşı ortak kültürel mirası sürdürme başarısını ve Türkiye'den de beklenen desteği ifade etmektedir. Diğer bir deyişle, Osmanlı ve Türk yönetimi bu coğrafyadan çekilse de Türklük ve Müslümanlık bu topluluklar üzerinden devam etmektedir.

Batı Trakya Müslüman-Türklerinin "biz burada bırakıldık" söylemini kullanmalarının diğer bir nedeni de bölgenin görece geç bir tarihte - hatta kısa süreli cumhuriyet sürecinden sonra- Yunanistan'ın idaresine verilmesi ve aniden kendilerini azınlık statüsünde bulmalarıdır. Osmanlı döneminde imparatorluk düzeyindeki idare Müslümanlara aitti ve imparatorluk ortadan kaybolduğunda toplumsal örgütlenmesinin bu k1smı onunla birlikte kayboldu. ${ }^{57}$ Geri kalanlar müftülerin önderlik ettiği dini kurumları, dini vakıfları, okulları, siyasi temsilleri ve gazeteleriydi. Köy düzeyinde, azınlığın sosyal organizasyonunun iki ayağı, cami ve okuldu. Diğer bir deyişle, Osmanlı devletinde Müslüman olmayan toplulukların merkezi yönetime karş1 uzun yıllar içerisinde oluşturduğu örgütlenme, dernekleşme, yayın organları kurma ve kimlik oluşturma sürecinden geçmediler, bu deneyime sahip değillerdir. Balkanlardaki Müslüman olmayan topluluklar ise dini bir lider etrafında birlik oluşturmuşlardır. Türkiye'nin seküler yönetime geçmesi ile birlikte dini liderlerin önemi de azalmıştır. Türk etnik kimliği bilincinin de Türkiye'de erken cumhuriyet döneminde gerçekleşen ulus-devlet kurma sürecinde ortaya çıktığı göz önüne alındığında bölgedeki ilk Türk derneklerinin- İskeçe Türk Gençler Yurdu ve Gümülcine Türk Gençler Birliği- 1927'de kurulması tesadüf değildir.

$\mathrm{Bu}$ yüzden diğer ilgi çeken nokta Osmanlı mirası bölgelerdeki Yunanistan, Bulgaristan ve Kıbrıs- Müslüman Türk topluluklarının Türkiye ile olan bağlarının sadece tarihsel boyutta kalmaması, ancak Türkiye'deki kültürel ve siyasal reformlardan da etkilenmeleri ve bu doğrultuda yeni iç kırılmalar yaşamalarıdır. ${ }^{58}$

$\mathrm{Bu}$ kırılmalar Osmanlı İslami yaşam geleneğini sürdürmek isteyen İslamcılar ile cumhuriyet Türkiyesi'nin seküler modernist ve Batı modelli reformlarını benimsemeyi tercih eden Kemalistler arasında ortaya çıkar.

\footnotetext{
${ }^{57}$ Aarbakke, The Muslim Minority of Greek Thrace, s. 88.

58 Taşkın, "SYRIZA's Electoral Victory in Greek Thrace", 2017, s. 161.; Kübra Öz, "Kıbrıs Türk Kimliğinin İnşasında Atatürk İlke ve İnkılâplarının Etkisi”, İnsan ve Toplum Bilimleri Araştırmaları Dergisi, Cilt 5, Say1 5, 2016, ss. 1262-1291; Giustina Selvelli, "The clash between Latin and Arabic Alphabets Among the Turkish Community in Bulgaria in the Interwar Period", Balkan Araştırma Enstitüsü Dergisi, Cilt 7, Sayı 2, Aralık 2018, ss. 367-390.
} 


\section{BURCU TAŞKIN}

Türkiye'de 1924 Tevhid-i Tedrisad Kanunu ile öğrenimde birlik gelirken tekke, zaviye ve türbeler de kapatılmıştır. $\mathrm{Bu}$ süreç Müslüman-Türk azınlığında cumacılar ve pazarcılar olmak üzere ikili öğrenim modelinin ortaya çıkmasına yol açar. İslamcılar kutsal gün olan Cuma günü okullarda ders yapmazken, Türkçü laik grup Türkiye'deki gibi Pazar günü okulları tatil yapmaktadır. Bu ayrım o kadar derinleşir ki müftüler seküler grubun evlenme, boşanma gibi işlemlerini yapmaz ve çocuklarına okulda eğitim vermeyi reddederler. Batı Trakya'da son şeyhülislam Mustafa Sabri ve 150'likler etkinliğini sürdürürken, Mehmet Hilmi onları eğitimin iyileşmesini engelleyen hainler olarak suçlar ve Türkiye'nin model alınması, Yeni Türk alfabesine geçilmesi için çalışır. ${ }^{59}$

Batı Trakya'da Yeni Türk alfabesi ile ilk gazete 1923 yılında yayınlanır, ancak yayın geleneği olmadığı için her iki taraf da doğrudan veya dolaylı olarak dışarıdan etkilenir. İslamcılar arasında Çapur İsmail Hakkı'nın İtilâ (1925-1930) ve Mustafa Sabri'nin Yarın (1927-1930) gazetelerinde Mustafa Kemal ve reform karşıtı söylemler göze çarparken, Türkiye'deki inkılabları destekleyen yayınlar daha çok Türkiye'de eğitim almış genç isimler tarafindan yürütülür. 1930 'da imzalanan 'ikamet, ticaret ve seyrisefain sözleşmesi'ne dayanarak İsmet İnönü'nün talebi üzerine diğer 150'liklerle beraber Yunanistan Mustafa Sabri'yi Batı Trakya'dan sürer. Mustafa Sabri sonrasinda Misır'a iltica eder. ${ }^{60}$

İslamc1-Kemalist gazete ayrımı 1950 ve 1960'larda Osman Nuri Fettahoğlu'nun Trakya ve muhafazakarlar Hüsnü Yusuf'un Sebat gazetelerinde devam eder. Azınlığın 1990'larda lideri konumunda olan ve Türkçülük politikasının baş aktörü Dr. Sadık Ahmet'in Balkan gazetesi, toplum içinde bölünme yarattığ 1 için muhalif İleri gazetesinde eleştirilmiştir.

1920'lerde başlayan muhafazakâr İslamcılar ve modernist Kemalistler çatışması eğitim, dernekleşme, basın yayın ve siyaset alanında 1970'lerde Kemalistlerin hâkim hale gelmesine kadar devam etmiştir. Bu kırılma zaten sosyal örgütlenmesini geç oluşturan azınlık grubunda birliği zayıflatıp, Yunan devletinin müdahalesine olanak sağlarken, siyasal ve sosyal

\footnotetext{
${ }^{59}$ Nilüfer Erdem, “Mehmet Hilmi’nin 'Yeni Adım Gazetesi’nde Batı Trakya Türklerinin Yeni Türk Alfabesine Geçmesi İçin Verdiği Mücadele”, Trakya Üniversitesi Sosyal Bilimler Dergisi, Cilt 14, Say1 2, Aralık 2012, ss. 157-178.

${ }^{60}$ Nilüfer Erdem, "Yunan Tarihçilerinin Gözüyle 1930 Türk-Yunan Dosltuk Antlaşması ve Venizelos'un Bu Sürece Katkıları”, Muğla Üniversitesi Sosyal Bilimler Enstitüsü Dergisi (ILKE), Say1 23, Güz 2009, s. 121.
} 


\section{TRİADİK BAĞ TEORİSİ BAĞLAMINDA BATI TRAKYA MÜSLÜMAN-TÜRK AZINLIĞININ TÜRKIYYE İLE BAĞLAYICI İLISSKİSİ}

dönüşümlerde Türkiye model alındığ için topluluğun Türkiye devleti ile olan bağlarını/ bağımlılıklarını kuvvetlendirmiştir. 1990'lardan sonra ise daha fazla Türkçü ve daha çok Yunan-karşıtı söylem göze çarpmaktadır. Yine de belirtmek gerekir ki farklı ideolojilere sahip olsalar da Türk-Yunan ve azınlıkYunan devleti ilişkilerine yönelik olarak tüm gazetelerin ortak görüşte oldukları göze çarpmaktadır. Bu gazeteler genelde, Yunan devletini azınlığın haklarını görmezden gelip ihlal ettikleri için suçluyorlar, Türk devletini de Batı Trakya'daki haklarının ve varoluşlarının garantörü olarak görüyorlar. Azınlık grubu arasındaki birleşmenin önemini vurgulayan yayınlarda, Türkler genellikle "saf, masum, duygusal, dürüst" olarak nitelendirilirken, Yunan devleti "kötü, istikrarsız politikalar yürüten ve dürüst olmayan"dır. Başlıca hedef ve sorunların nedeni Yunan devletidir. Yunan halkı bu açıklamaların dışında tutulur ve Türk basınında yer almaz.

Yukarıda belirtildiği gibi hem Yunanistan'da hem de Türkiye'de uluslararası alanda tanınan ve etkili ruhani dini bir önderi olmayan cemaat için yerel elitler ve siyasi liderler önem kazanmıştır. Bu boşluğu kısa sürede dolduran Türkçülük politikasının mimarlarından olan, etnik parti Dostluk Eşitlik ve Barış Partisi'nin kurucularından ve meseleyi uluslararasılaştırmayı başaran Sadık Ahmet'in 1995 senesinde bir trafik kazasında hayatını kaybetmesi topluluğu tekrar lidersiz bırakmıştır.

Her ne kadar ABTTF, diğer AB ve azınlık kurumları azınlık haklarını ve ihlallerini gündeme getirmeye devam etse de, lidersizlik durumu Yunan devletinin politikalarına karşı ortak ve güçlü politika geliştirme yeterliliğini azaltırken, haklarının korunması konusunda azınlığın yine Türkiye devletine bağımlılı̆̆ını arttırmıştır. Batı Trakya azınlık milletvekilleri 1920 senesinden itibaren Yunan Parlamentosu'nda olmalarına rağmen 1970'lerin ortasına kadar mecliste bir iz bırakmamışlardır. Bunun da en büyük nedeni Yunanca'ya yeterince hâkim olmamaları ve daha çok cemaat ile merkezi yönetim arasında aracı kişi olarak hizmet vermeyi tercih etmeleridir.

Bu noktada yine İslamcı-Kemalist ayrımı azınlık siyasetçiler arasında iç çekişmeleri getirmiş, azınlık talepleri ve sorunları üzerinde birlik olamamıştır. 1970'lerin ortasından itibaren azınlığın hem Yunanca diline hâkim, hem de Türkiye'de üniversite eğitimi almış yüksek tahsilli, doktor, dişçi, öğretmen ve avukat gibi toplulukta etki gücü yüksek kişiler tarafindan Yunan meclisinde temsil edilmesi, azınlık sorunlarının daha geniş kesimlere ulaşmasında fayda sağlamıştır. Ancak yine son dönemde ruhani veya siyasi 


\section{BURCU TAŞKIN}

lider eksikliği Müslüman-Türk azınlığın mevcudiyetini ve haklarından yararlanmasını Yunan devletinin keyfi politikalarına açık hale getirmiştir.

Özellikle 1993 senesinde \%3 seçim barajının hem siyasi partiler hem de bağımsız adaylar için uygulanmaya konulması ile birlikte özerk siyasal örgütlenmeden ziyade ulusal Yunan partileri içinde çalışmalar ve temsiliyet tercihi ön plana çıkmıştır. 1993 genel seçimlerinde seçilme şansının olmadıklarını bildikleri halde azınlık topluluğu DEB'in bağımsız aday listesine oy vermiş, Müslüman azınlık ilk kez Yunan meclisinde temsilcisiz kalmıştır. DEB ise Rodop seçim bölgesinde birinci parti çıkmasına dayanarak "içeride ve dışarıda Müslüman azınlığın tek temsilcisi” olduğunu "azınlıkla ilgili kararlarda kendilerine danışılması gerektiğini" ifade etmiştir. ${ }^{61} \mathrm{Bu}$ da çoğunluk Yunan halkının ve seçildikleri partilerin tepkisini çekmemek için daha 1 lımlı politikalar yürütmelerini gerektirmektedir. Her seçim dönemi azınlık cemaati ve milletvekilleri Yunan partilerinin azınlık sorunlarına yönelik vaadleri üzerinden tercihler yapmakta; ancak sorunların çözülmesinde gerekli ve istikrarlı iradeyi gösteremeyen -çoğu zaman milliyetçi tepkilerden çekinen- Yunan hükümetleri tarafindan hayal kırıklığına uğratılmaktadır. Bunun yanında Türkiye ve Yunanistan arasındaki ilişkilerin, çözülemeyen konular - Kıbrıs ve Ege meselesi- yüzünden gerilimli olduğu dönemlerde her iki ülkede de azınlıklara karşı hak ihlalleri artmaktadır.

İskeçe ve Gümülcine'de yerel seçimlerde Müslüman temsilcilerin sayısının artması ulusal düzeyde azınlık meselesi ve Yunan devletinin baskıları konusunda farkındalığı arttırırken, tarihsel olarak İslamlaşma korkusu yaşayan Yunan halkı arasında azınlık- çoğunluk gerilimini de getirmektedir. $^{62}$ 2000'lerin ortasından sonra özellikle Avrupa'da İslamifobia'nın artması, aşırı sağın yükselişi ve Yunanistan'da da Altın Şafak partisinin tabansal güç elde etmesi sonucu son zamanlarda Müslüman mezarlıklarının ve ibadethanelerinin saldırıya uğraması ve arttan ırkçı

${ }^{61}$ Balkan gazetesi Arşivi, 87/13.10.1993.

${ }^{62}$ Elefteros Tipos gazetesi seçim sonuçlarını "Hassas Dengeler: Azınlık ve Rodop'ta 3 Milletvekili” olarak değerlendirdi (22 Eylül 2015). Öte yandan, Estia gazetesi "3 Müslüman Tehdit” başlığı kullandı (25 Eylül 2015). Popülist-sağ kanat gazetesi Dimokratia sonuçları ilk sayfasında kalın ve büyük fontlar ile: "Ülkemizin en hassas (!!!) bölgesi üç Müslüman ile temsil edilecek" başlı̆g 1 ve alt başlıklarda "Rodop Hristiyan milletvekilsiz" ve "Kontrolsüz Türk Konsolosluğu" olarak verdi. Haberde Türk ve Yunan bayraklarını kullanması tehditin sadece İslamlaşma değil aynı zamanda bölgedeki Türk etkisine de işaret ediyor. (22 Eylül 2015). 


\section{TRİADİK BAĞ TEORİSİ BAĞLAMINDA BATI TRAKYA MÜSLÜMAN-TÜRK AZINLIĞININ TÜRKIYYE İLE BAĞLAYICI İLIŞKİSI}

yaklaşımlar azınlık topluluğunu tedirgin etmektedir. ${ }^{63}$ Yunanistan günlük hayatında ve siyasetinde etkin aktör olan Ortodoks kilisesi de Müslüman azınlığı Osmanlı'nın devamı, İslamın bir parçası, cihatçı ve Türk ajanı olarak tanımlamaktadır. ${ }^{64}$

Triadik bağ1 oluşturan bir diğer nokta da 1923 Lozan Antlaşması'ndan ileri gelen 'mütakabiliyet ilkesi' dir. Müslüman Türk azınlık ve Türkiye devleti yapılan hak ihlallerinde Lozan Antlaşmasına ve bu anlaşmanın azınlıkların korunmasını içeren maddelerine referansta bulunmaktadır. Müftülük kurumunun yetkinliğini belirleyen 1913 Atina Antlaşmasının yanısıra azınlık vakıflarının özerkliğine değinen 1920 Yunan İç Hukuku ve özellikle 1923 Lozan Antlaşması, Müslüman-Türk azınlık tarafindan anayasa olarak görülmektedir. Bu noktada Türkiye'nin garantör ülke olarak müdahale etmesine ve pazarlık gücü olarak 'mütakabiliyet ilkesini' kullanmasına karşı değiller. Ancak bu pazarlık hususunda iki çelişki dikkatleri çekiyor. Makalenin başında da belirtildiği gibi Rum Ortodoks cemaatin gittikçe azalan sayısı karşısında bu ilkeyi savunmak ve Yunan-Türk ilişkilerinin inişli çıkışlı yapısı düşünüldügünde Türkiye'ye bağlılık ileriye dönük kazanımlarda çok mantıklı gözükmüyor. Diğer yandan Türkiye'nin kendi yaptığı/yapacağ1 olumlu adımlara karşılık mütakabiliyet arzuladığı/istediği konular da birebir denk gözükmüyor. Heybeliada Ruhban Okulu'nu açmak için Türk devleti Atina'da bir caminin kurulmasını talep etmekteydi; bu, bölgesel haklara sahip olan ve içinde yaşadıkları illerde cami ve mezarlık bulunan Müslüman azınlık için birincil talep değildir. Benzer şekilde, müftü kurumunun Patrikhane veya Ruhban okulu ile karşılaştırılması, yalnızca koşulların iyileştirilmesine giden yolu engellemektedir. Öncelik azınlığın en önemli sorun olarak gördüğü kaliteli modern Türkçe ve Yunanca eğitimin verilmesi, azınlığın kendi vakıflarının idaresine sahip olması ve müftülük kurumundaki ikibaşlılığın kaldırılması olarak sunulabilir. ${ }^{65} \mathrm{Bu}$ noktada müftülerin, Patrikler gibi başta yerel dil olmak üzere farklı dilleri konuşabilme, kucaklayıc1, cemaati birleştirici,

\footnotetext{
${ }^{63}$ Yunanistan'ın Dedeağaç kentinde Müslüman mezarlığına 1rkçı saldırı bkz.: "Yunanistan, Yunanlara ait", https://tr.euronews.com/2019/05/29/yunanistanin-dedeagac-kentindemusluman-mezarligina-irkci-saldiri-yunanistan-yunanlara-ait. Rodos Adası'ndaki Müslüman Mezarlığına Çirkin Saldırı https://www.haberler.com/rodos-taki-musluman-mezarliginacirkin-saldiri-5709677-haberi/, (11.06.2019).

${ }^{64}$ Umut Özkırımlı ve Sypros Sofos, Tormented by History: Nationalism in Greece and Turkey, Columbia Press, Newyork 2008, s. 159.

65 İskeçe Siriza milletvekili Hüseyin Zeybek ile mülakat, 23 Nisan 2013; Gümülcine Siriza eski milletvekili Ayhan Karayusuf ile mülakat, 22 Nisan 2013.
} 


\section{BURCU TAŞKIN}

saygınlık uyandıran ve meseleyi uluslararası alana taşıyabilecek, gerekirse liderlik rolünü üstlenebilecek yeterlilikleri edinmesi faydalı olacaktır.

\section{Sonuç ve Tartışmalar}

Ulusal azınlıklar hak ve talepleri konusunda siyasal davranışlar geliştirirken yaşadıkları uluslaşmakta olan ve vatandaşı olunan ülke ile aynı etnik, kültürel ve dini özellikleri paylaştıkları soydaş ülke arasında triadik/üçlü bağ çerçevesinde ilişki kurarlar. Batı Trakya Müslüman-Türk azınlık cemaatinin yerel, ulusal ve uluslararası alandaki temsiliyetlerinde de benzer bir ilişki kurdukları görülmüştür. Bu bağlamda cemaatin kültürel dernekleşmesini geç oluşturması, grup arasındaki ideolojik çatışmalar ve özellikle Kemalist-İ̀slamist ayrımı temelli bölünmeler, yerel dile hâkimiyetteki yetersizlikleri, eğitim seviyesinin düşük kalması ve bunun yanında ruhani veya siyasi bütünleştirici bir liderinin bulunmaması, onların soydaş ülke olarak gördükleri Türkiye'ye bağlarının/bağımlılıklarının güçlü bir şekilde devam etmesini doğurmuştur. Bu noktada nesilden nesile aktarılan "biz burada bırakıldık" söylemi aslında haklarının korunması ve iyileştirilmesi için "mütakabiliyet ilkesinin" uygulanması çok mantıklı gözükmese de, azınlığın Yunan devleti ile olan güven sorunlarının aşılamaması ve hak ihlallerinde uluslararası kamuoyundan yeterli destek görülemediği için Türkiye'nin koruyucu soydaş ülke olarak konumlanması ve sorumlu tutulması tarihsel, rasyonel nedenlere oturmaktadır. Bunun yanında "biz burada bırakıldık" söylemi ile Lozan Antlaşması'na taraf olan diğer ülkeler ve uluslararası kamuoyu da Müslüman-Türk azınlığı mübadeleden muaf tuttukları için bu cemaatin güvenliğinden ve haklarından serbestçe yararlanmasından sorumlu görülmektedir.

Sonuç olarak aslında Müslüman-Türk azınlığı sorunların çözümü ve koşullarının iyileştirilmesi için hem Yunan hükümeti ve hem de Türkiye devleti ile temas içindedir. Problemler meclisteki azınlık temsilcileri tarafından dile getirilmektedir. İlk olarak sorunların çözümü için iç ilişkiler ve temaslar kullanılmaktadır. Ancak, Yunan hükümetinin basit meselelerin çözümünde İslamlaşma ve Türkleşme tehditi bahanesi ile gerekli adımları atmaktan imtina etmesi, irade ve istek eksikliği cemaat ile arasında güven sorunu yaratmaktadır.

Azınlıkların vatandaşı oldukları devlete güven duyması için somut adımları görmesi ve bu adımların samimi olduğuna ikna olması gerekir. 


\section{TRİADİK BAĞ TEORİSİ BAĞLAMINDA BATI TRAKYA MÜSLÜMAN-TÜRK AZINLIĞININ TÜRKIYYE İLE BAĞLAYICI İLIŞKİSI}

Topluluk yaşadıkları hak ihlallerini uluslararası alana taşısa da Yunan devleti bu yaptırımları göz ardı etmeye devam etmektedir. Bu da azınlık-çoğunluk arasındaki "güven teorileri”ne bakıldığında Müslüman-Türk azınlığın daha çok içine kapalı bir yapı oluşturmasına yol açmaktadır. Diğer bir deyişle azınlığın problemleri ile Türkiye dışında ilgilenecek ve haklarını koruyacak başka bir aktör yok algısını doğurmaktadır. Örneğin 1990'ların başında azınlığın atanan müftüleri tanımayıp Gümülcine'de İbrahim Şerif ve İskeçe'de Mehmet Emin Ağa' yı kendi müftüsü olarak seçmesi üzerine Yunan devleti müftülerin görevlerini yapmasını engellemiş, birçok dava açmış ve Mehmet Emin Ağa sonunda 136 ay hapis cezasına mahkûm olmuştur. Bunun üzerine dönemin Dışişleri Bakanı Karayalçın, Mehmet Emin Ağa'nın bırakılmaması durumunda Türkiye'nin gerekli adımları atacağını belirtmiş, dönemin Başbakanı Tansu Çiller de Ağa ailesini ziyaret etmiştir. ${ }^{66}$ Konu Türkiye tarafindan uluslararasılaştırılmış ve azınlık cemaati başvurusu ile AİHM'ne taşınmış, Yunan devleti haksız bulunup tazminat ödemeye mahkûm olsa da, aynı uygulama bugüne kadar devam etmiştir. Böylece Yunan devleti Sadık Ahmet davasında olduğu gibi cemaatin ruhani veya siyasi bir lider etrafında politize ve mobilize olmasını engellemiştir.

Diğer yandan Türkiye, benzer bir tutumunu sürdürmüş, Yunanistan hükümeti 2014 senesinde "240 imam yasası" olarak bilinen azınlık okullarında din ve Kur'an derslerinin Yunanca verilmesini kararlaştıran tasarıya karşı 'mütakabiliyet ilkesi' tehdidi ile karşılık vermiştir. ${ }^{67}$ Kısır döngü olarak, azınlığa danışılmadan alınan bu kararlar ve azınlığın lidersiz bırakılması Türkiye ile yakın bağları -ve bunun tersi- arttırırken, Yunanistan'daki çoğunluk ve azınlık nüfusu arasındaki güvensizliği çoğaltmaktadır.

Brubaker'in triadik bağ teorisine soydaş ve yaşanılan ülkenin yanısıra uluslararası kamuoyu da dördüncü aktör olarak eklenebilir. Günümüzde insan haklarına ve azınlık haklarına daha duyarlı bir kamuoyu, Minority Right Group (Azınlık Hakları Grubu) ve Helsinki Watch Group (Helsinki İzleme Grubu) gibi etkili sivil toplum örgütlenmeleri bulunmaktadır. Türkiye ve Yunanistan'in 2000'lerin başında oluşturduğu olumlu iklim ve Yunanistan'ın Türkiye'nin Avrupalılaşma sürecine olan desteği azınlıklarına karşı

\footnotetext{
66 Milliyet, "Yunanistan'a İskeçe Uyarısı”, 1 January 1995, http://gazetearsivi.milliyet.com.tr/Arsiv/1995/01/25, (13.07.2019).

${ }_{67}$ Batı Trakya Online, "Yunanistan'ın bu yaptığı saygisızlıktır", http://www.batitrakya.org/bati-trakya/bati-trakya-haber/bozdag-yunanistanin-bu-yaptigisaygisizliktir.html, (13.07.2019).
} 
yaklaşımlarını da bir tehdit unsurundan tarihsel bağı oluşturan aktörler konumuna getirmiştir. Bununla birlikte, bu ülkelerin demokratikleşme ve Avrupalılaşma sürecine rağmen, hem Yunanistan hem de Türkiye'nin azınlık toplulukları ile ilgili sorunları devam etmektedir. Yunanistan'1n 1981'den bu yana AB'ye üye olmasına rağmen, Müslüman azınlığının sorunlarını görmezden gelmeye devam etmesi, AB üyeliğinin ve devlet-dış1 aktörlerin azınlığın koşullarında veya siyasi temsilinde iyileşmeyi doğrudan garanti etmediğini göstermektedir. Bu yüzden de iki ülkenin de birbirlerinin içişlerine karışmaması, azınlıklarını tehdit değil kendi vatandaşları olarak görerek sorunları iç hukukla çözme yollarını aramaları meselenin çözüm olasılığını arttıracaktır.

Sol görüşü nedeniyle bu sorunları çözebilecek tek parti olabileceği inancıyla azınlık seçmeni SİRİZA'ya 2012 ve 2015 seçimlerinde destek vermişti. ${ }^{68}$ Ancak SİRIZA'nın kendisine seçtiği koalisyon ortağının aşırı milliyetçi ANEL olması, iktidarı ele aldığından bu yana izlediği politikalar, bu konuda ne sözde, ne de özde girişimlerinin olmaması, SİRİZA hükümetine yönelik beklentilerini yüksek tutan azınlık insanı için bir hayal kırıklığı oldu. Temmuz 2019 seçimlerinde aşırı sağ parti Altın Şafak'ın baraj altında kalması azınlık-çoğunluk gerilimi açısından olumlu bir sonuç getirirken, merkez-sağ Yeni Demokrasi partisinin tek başına iktidara gelmesinin Müslüman-Türk azınlığın sorunları için nasıl sonuçlar getireceğini göreceğiz. Ana muhalefet partisi SİRIZZ'nın İskeçe ilinde azınlıktan aldığ 1 yüksek oy ve meclise 3 milletvekili göndermesi son dönemde olumlu beklentiler doğururken, ${ }^{69} 2004$ senesinden beri sağ partilerden temsilci çıkaramayan azınlığın partiler arası denge politikası yürütmesini de getirebilir.

\footnotetext{
${ }^{68}$ Taşkın, a.g.m., s. 179.

69 "Yunanistan seçimlerinde büyük sürpriz! Yunan Parlamentosu'na üç Türk girdi", https://www.sozcu.com.tr/2019/dunya/son-dakika-yunan-parlamentosunda-uc-turk-5219065/, (13.07.2019).
} 


\section{TRİADİK BAĞ TEORİSİ BAĞLAMINDA BATI TRAKYA MÜSLÜMAN-TÜRK AZINLIĞININ TÜRKIYYE İLE BAĞLAYICI İLIŞKİSİ}

\section{KAYNAKÇA}

AARBAKKE, Vermund, The Muslim Minority of Greek Thrace, Doktora Tezi, University of Bergen, Bergen 2000.

ALDERMAN, Geoffrey ve JOHN, Leslie, Governments, Ethnic Groups and Political Representation: Comparative Studies on Governments and Nondominant Ethnic Groups in Europe, 1850-1940, Dartmouth Publishing, New York 1993.

ALİĞLLU, Cafer, Batı Trakya Davası'nın Avrupa Cephesi, İnal Ofset, İstanbul 1998.

ANAGNOSTOU, Dia ve TRIANDAFYLLIDOU, Anna, "Regions, minorities and European integration: A case study on Muslims in Western Thrace, Greece", http://www.eliamep.gr/wpcontent/uploads/en/2006/05/Case_study_report_Thrace.pdf, Eliamep Report, 2006, (1.10.2014).

BAR-TAL, Daniel, TEICHMAN, Yona, Stereotypes and Prejudice in Conflict: Representations of Arabs in Israeli Jewish Society, Cambridge University Press, Cambridge 2005.

BASTIAN, Brock ve LUSHER, D., ATA, A., "Contact, evaluation and social distance: Differentiating majority and minority effects", International Journal of Intercultural Relations, Say1 36, 2000, ss. 100-117.

BİLALİ, Rezarta ve ÇELIK, A. Betül ve OK, Ekin, "Psychological asymmetry in minority-majority relations at different stages of ethnic conflict", International Journal of Intercultural Relations, Cilt 43, 2014, ss. 253-264.

BRUBAKER, Rogers, Nationalism Reframed: Nationhood and the National Question in the New Europe, Cambridge University Press, New York 1996.

CERCEL, Cristian, "Postwar (West) German-Romanian Relations: Expanding Brubaker's Analytic Triad", Nationalism and Ethnic Politics, Cilt 23, Say1 3, 2017, ss. 297-317. 


\section{BURCU TAŞKIN}

CİN, Turgay, Yunanistan'daki Müslüman Türk Azınlığın Din ve Vicdan Özgürlügü: Baş Müftü ve Müftülükler Sorunu, Seçkin Yayınları, Ankara 2003.

CLOGG, Richard, A Concise History of Grece, Cambridge Pub., Cambridge 2002.

CRAMPTON, Richard J, A Concise History of Bulgaria (Cambridge Concise Histories), 2. Bask1, Cambridge University Press, New York 2006.

DEDE, Abdürrahim, Rumeli'de Bırakılanlar, Batı Trakya Türkleri, Otağ Matbaas1, İstanbul 1975.

EDWARDS, John, "Sociopolitical aspects of language maintenance and loss: towards a typology of minority language situations", Maintenance and Loss of Minority Languages, (ed.) W. Fase ve K. Jaspaert ve S. Kroon, John Benjamins Publishing Co., Amsterdam 1992.

ERDEM, Nilüfer, "Yunan Tarihçilerinin Gözüyle 1930 Türk-Yunan Dosltuk Antlaşması ve Venizelos'un Bu Sürece Katkıları", Muğla Üniversitesi Sosyal Bilimler Enstitüsü Dergisi (ILKE), Sayı 23, Güz 2009, ss. 93-128.

"Mehmet Hilmi'nin 'Yeni Adım Gazetesi'nde Batı Trakya Türklerinin Yeni Türk Alfabesine Geçmesi İçin Verdiği Mücadele", Trakya Üniversitesi Sosyal Bilimler Dergisi, Cilt 14, Say1 2, 2012, ss. 157-178.

FEATHERSTONE, Kevin ve NIARCHOS, Giorgos, The Last Ottomans: The Muslim Minority of Greece, 1940-1949, Palgrave Macmillan, New York 2011.

HOROWITZ, Donald L., Ethnic groups in conflict. University of California Press, Berkeley 1985.

HUGHES, Diana ve RODRIGUEZ, J. ve SMITH E. P., Johnson, D., Stevenson, H., \& Spicer, P., "Parents' ethnic-racial socialization practices: A review of research and directions for future study", Developmental Psychology, Cilt 42, 2006, ss. 747-770.

HÜSEYINOĞLU, Ali, "Türk-Yunan Nüfus Mübadelesinin "Kalanlar" / "Bırakılanlar" Boyutu: Yunanistan’daki Batı Trakya Türkleri ve Geçmişten 


\section{TRİADİK BAĞ TEORİSİ BAĞLAMINDA BATI TRAKYA MÜSLÜMAN-TÜRK AZINLIĞININ TÜRKIYYE İLE BAĞLAYICI İLIŞKİSİ}

Günümüze Azınlık Eğitimi”, 6. Uluslararası Mübadele ve Balkan Türk Kültürü Araştırmaları Kongresi Bildirileri, Cilt 9, 2014, ss. 239-256.

JENNE, Erin K., Ethnic Bargaining: The Paradox of Minority Empowerment, Cornell University Press, Ithaca 2007.

KONTOGIORGI, Elisabeth, Population Exchange in Greek Macedonia: The Forced Settlement of Refugees 1922-1930, Clerdon Press, Oxford 2006.

KYMLICKA, Will, Multicultural Citizenship, Oxford University Press, Oxford 1995.

LERNER, Natan, Group Rights and Discrimination in International Law, Martinus Nijhoff Publishers, Dordrecht/Boston/London 1991.

MYLONAS, Haris, The Politics of Nation-Building Making Co-Nationals, Refugees, and Minorities, Cambridge University Press, New York 2012.

ORAN, Baskın, Türk Yunan İlişkilerinde Batı Trakya Sorunu, Mülkiyeliler Birliği Yayınları, Ankara 1992.

ÖZ, Kübra, "Kıbrıs Türk Kimliğinin İnşasında Atatürk İlke ve İnkılâplarının Etkisi”, Insan ve Toplum Bilimleri Araştırmaları Dergisi, Cilt 5, Sayı 5, 2016, ss. 1262-1291.

ÖZGÜÇ, Adil, Batı Trakya Türkleri, Kutluğ Yayınları, İstanbul 1974.

ÖZKIRIMLI, Umut ve SOFOS, Sypros, Tormented by History: Nationalism in Greece and Turkey, Columbia Press, New York 2008.

PREECE, Jennifer J., National Minorities and the European Nation-States System, Oxford University Press, New York 1998.

RAIKKA, Juhn, Do We Need Minority Rights? Conceptual Issues, Martinus Nijhoff Publishers, Boston 1996.

SELVELLI, Giustina, "The Clash between Latin and Arabic Alphabets Among the Turkish Community in Bulgaria in the Interwar Period", Balkan Araştırma Enstitüsü Dergisi Cilt 7, Sayı 2, Aralık 2018, ss. 367-390. 


\section{BURCU TAŞKIN}

SERDAR, Ahmet, "Tarihsel Süreç İçerisinde Batı Trakya Türklerinin Ekonomik ve Demografik Gelişimi”, Balkan Araştırma Enstitüsü Dergisi, Cilt 3, Say1 2, Aralık 2014, ss. 97-126.

STAVROS, Stephanos, "The Legal Status of Minorities in Greece Today: The Adequacy of their Protection in the Light of Current Human Rights Perceptions", Journal of Modern Greek Studies, Cilt 13, No. 1, 1995, ss. 132.

STEPHAN, Walter G.ve C.W. Stephan, "Intergroup anxiety", Journal of Social Issues, Cilt 81, 1985, ss. 157-175.

TAŞKIN, Burcu, Political Representation of Minorities in Greece and Turkey: Nationalism, Reciprocity and Europeanization, Libra Publisher, Istanbul 2019.

"SYRIZA's Electoral Victory in Greek Thrace: Impact of Muslim Minority Vote in the Changing Political System", Nationalism and Ethnic Politics, Cilt 23, Say1 2, 2017, ss. 155-181.

TSITSELIKIS, Kostantinos ve MAVROMMATIS, Giorgos., "The Turkish language in Education in Greece", Mercator-Education Report, 2003.

WHITMAN, Lois, Destroying Ethnic Identity - The Turks of Greece, Helsinki Watch Report, New York 1990.

VAN HOUTEN, Pieter, "The role of a minority's reference state in ethnic relations", European Journal of Sociology, Cilt 39, Say1 1, 1998, ss. 110-146.

YAKINKILIÇ, Kadir, KUTLAY, Yağmur, "Batı Trakya Türklerinin Anadillerine ve Kültürlerine Karşı Tutumları”, Bilig, Say1 70, ss. 283-308.

\section{İnternet Kaynakları}

Batı Trakya, "Yunanistan'ın bu yaptığı saygısızlıktır", 8 Ağustos 2013, http://www.batitrakya.org/bati-trakya/bati-trakya-haber/bozdagyunanistanin-bu-yaptigi-saygisizliktir.html, (13.07.2019). 


\section{TRİADİK BAĞ TEORİSİ BAĞLAMINDA BATI TRAKYA MÜSLÜMAN-TÜRK AZINLIĞININ TÜRKIYYE İLE BAĞLAYICI İLIŞKİSİ}

DailySabah, "Tsipras First Greek Leader in Decades to Visit Historic Istanbul Seminary", 7 Şubat 2019, https://www.dailysabah.com/politics/2019/02/07/tsipras-first-greek-leaderin-decades-to-visit-historic-istanbul-seminary, (22.02.2019).

EuroNews, "Yunanistan'ın Dedeağaç kentinde Müslüman mezarlığına 1rkçı saldırı: 'Yunanistan, Yunanlara ait", 29 May1s 2019, https://tr.euronews.com/2019/05/29/yunanistanin-dedeagac-kentindemusluman-mezarligina-irkci-saldiri-yunanistan-yunanlara-ait, (09.06.2019).

European Elections 2019 Results; https://election-results.eu/nationalresults/greece/2019-2024/. (25.03.2019).

Greek Reporter, "Who is Responsible for Letting Turkey Influence Greek Muslim Minority in Thrace", 28 May1s 2019, https://greece.greekreporter.com/2019/05/28/whos-responsible-for-lettingturkey-influence-greek-muslim-minority-in-thrace/, (09.06.2019).

GündemGazetesi, "Ruhban Okulu'na Karş1 Müftülük”, 8 Şubat 2019, http://www.gundemgazetesi.com/PDF/gundem_1051.pdf, (11.04.2019).

Gündem Gazetesi, “Çipras'ın Türkiye Ziyaretinden Azınlık Ne Bekliyor”, 15 Şubat 2019, http://www.gundemgazetesi.com/PDF/gundem_1050.pdf, (11.04.2019).

Haberler.com, "Rodos Adası'ndaki Müslüman Mezarlı̆̆ına Çirkin Saldırı", 24 Şubat 2014, https://www.haberler.com/rodos-taki-musluman-mezarliginacirkin-saldiri-5709677-haberi/, (11.06.2019).

Milliyet,"Yunanistan'a İskeçe Uyarısı", 1 Ocak 1995, http://gazetearsivi.milliyet.com.tr/Arsiv/1995/01/25, (13.07.2019).

Ministery of Foreign Affairs, "Batı Trakya Türk Azınlığı", www.mfa.gov.tr/bati-trakya-turk-azinligi.tr.mfa,(18.03.2014).

NTV, "Yunanistan Başbakanı Çipras'tan Ayasofya'ya ve Heybeliada Ruhban Okulu'na Ziyaret", 7 Şubat 2019, https://www.ntv.com.tr/galeri/dunya/yunanistan-basbakani-ciprastanayasofyaya-ve-heybeliada-ruhban-okuluna- 


\section{BURCU TAŞKIN}

ziyaret,G344wH8WWkul_K68uXUx_A/gIkteVWipU64Zp9xDXVHaw, (22.02.2019).

Sabah, "Batı Trakya'da Müftü Atamasını Eleștiren Gazetecilere Hapis", 8 Haziran 2018, https://www.sabah.com.tr/dunya/2018/06/08/bati-trakyadamuftu-atamasini-elestiren-gazetecilere-hapis, (17.09.2018).

Sözcü, "Yunanistan seçimlerinde büyük sürpriz! Yunan Parlamentosu'na üç Türk girdi”, 8 Temmuz 2019, https://www.sozcu.com.tr/2019/dunya/sondakika-yunan-parlamentosunda-uc-turk-5219065/, (13.07.2019).

Yurtdışı Türkler ve Akraba Topluluklar Başkanlığı (YTB), "Akraba Topluluklar", https://www.ytb.gov.tr/, (11.03.2019). 